4

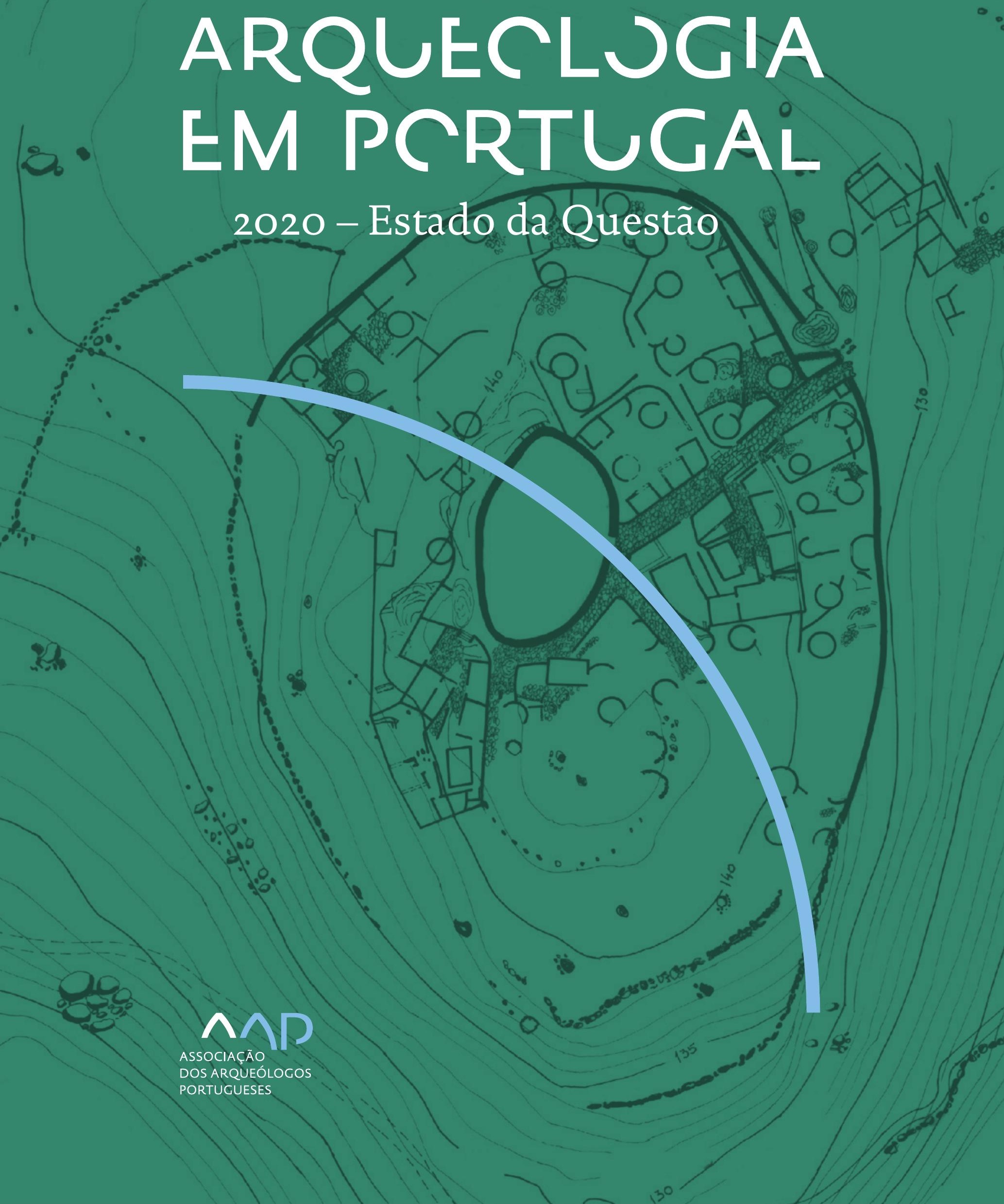


Coordenação editorial: José Morais Arnaud, César Neves e Andrea Martins Design gráfico: Flatland Design

AAP - ISBN: 978-972-9451-89-8

CITCEM - ISBN: 978-989-8970-25-1

Associação dos Arqueólogos Portugueses e CITCEM

Lisboa, 2020

O conteúdo dos artigos é da inteira responsabilidade dos autores. Sendo assim a Associação dos Arqueólogos Portugueses declina qualquer responsabilidade por eventuais equívocos ou questões de ordem ética e legal.

Desenho de capa:

Planta do castro de Monte Mozinho (Museu Municipal de Penafiel).

\section{$\hat{\wedge} \mathrm{P}$}

DOS ARQUEÓLOGOS PORTUGUESES

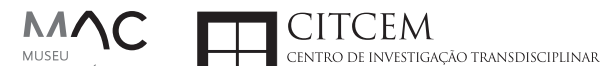
MUSEU
ARQUELLÓGICO
DO CARMO
U.PORTO

FLUP FACULDADE DE LETRAS
UNIVERSIDADE DO PORTO

Apoio

EC para a Ciência 


\section{Índice}

15 Prefácio

José Morais Arnaud

\section{Historiografia e Teoria}

17 Território, comunidade, memória e emoção: a contribuição da história da arqueologia (algumas primeiras e breves reflexões)

Ana Cristina Martins

25 Como descolonizar a arqueologia portuguesa?

Rui Gomes Coelho

41 Arqueologia e Modernidade: uma revisitação pessoal e breve de alguns aspetos da obra homónima de Julian Thomas de 2004

Vítor Oliveira Jorge

57 Dados para a História das Mulheres na Arqueologia portuguesa, dos finais do século XIX aos inícios do século XX: números, nomes e tabelas

Filipa Dimas / Mariana Diniz

73 Retractos da arqueologia portuguesa na imprensa: (in)visibilidades no feminino

Catarina Costeira / Elsa Luís

85 Arqueologia e Arqueólogos no Norte de Portugal Jacinta Bugalhão

101 Vieira Guimarães (1864-1939) e a arqueologia em Tomar: uma abordagem sobre o território e as gentes

João Amendoeira Peixoto / Ana Cristina Martins

115 Os memoráveis? A arqueologia algarvia na imprensa nacional e regional na presente centúria (2001-2019): características, visões do(s) passado(s) e a arqueologia

enquanto marca

Frederico Agosto / João Silva

129 A Evolução da Arqueologia Urbana e a Valorização Patrimonial no Barlavento Algarvio: Os casos de Portimão e Silves

Artur Mateus / Diogo Varandas / Rafael Boavida

\section{Gestão, Valorização e Salvaguarda do Património}

145 O Caderno Reivindicativo e as condições de trabalho em Arqueologia Miguel Rocha / Liliana Matias Carvalho / Regis Barbosa / Mauro Correia / Sara Simões / Jacinta Bugalhão / Sara Brito / Liliana Veríssimo Carvalho / Richard Peace / Pedro Peça / Cézer Santos

155 Os Estudos de Impacte Patrimonial como elemento para uma estratégia sustentável de minimização de impactes no âmbito de reconversões agrícolas Tiago do Pereiro

165 Salvaguarda de Património arqueológico em operações florestais: gestão e sensibilização Filipa Bragança / Gertrudes Zambujo / Sandra Lourenço / Belém Paiva / Carlos Banha / Frederico Tatá Regala / Helena Moura / Jacinta Bugalhão / João Marques / José Correia / Pedro Faria / Samuel Melro

179 Os valores do Património: uma investigação sobre os Sítios Pré-históricos de Arte Rupestre do Vale do Rio Côa e de Siega Verde José Paulo Francisco 
189 Conjugando recursos arqueológicos e naturais para potenciar as visitas ao Geoparque Litoral de Viana do Castelo (Noroeste de Portugal)

Hugo A. Sampaio / Ana M.S. Bettencourt / Susana Marinho / Ricardo Carvalhido

203 Áreas de Potencial Arqueológico na Região do Médio Tejo: Modelo Espacial Preditivo Rita Ferreira Anastácio / Ana Filipa Martins / Luiz Oosterbeek

223 Património Arqueológico e Gestão Territorial: O contributo da Arqueologia para a revisão do PDM de Avis

Ana Cristina Ribeiro

237 A coleção arqueológica do extinto Museu Municipal do Porto - Origens, Percursos e Estudos

Sónia Couto

251 Valpaços - uma nova carta arqueológica

Pedro Pereira / Maria de Fátima Casares Machado

263 Arqueologia na Cidade de Peniche

Adriano Constantino / Luís Rendeiro

273 Arqueologia Urbana: a cidade de Lagos como caso de Estudo Cátia Neto

285 Estratégias de promoção do património cultural subaquático nos Açores. O caso da ilha do Faial

José Luís Neto / José Bettencourt / Luís Borges / Pedro Parreira

297 Carta Arqueológica da Cidade Velha: Uma primeira abordagem

Jaylson Monteiro / Nireide Tavares / Sara da Veiga / Claudino Ramos / Edson Brito /

Carlos Carvalho / Francisco Moreira / Adalberto Tavares

311 Antropologia Virtual: novas metodologias para a análise morfológica e funcional Ricardo Miguel Godinho / Célia Gonçalves

\section{Didáctica da Arqueologia}

327 Como os projetos de Arqueologia podem contribuir para uma comunidade culturalmente mais consciente Alexandra Figueiredo / Claúdio Monteiro / Adolfo Silveira / Ricardo Lopes

337 Educação Patrimonial - Um cidadão esclarecido é um cidadão ativo! Ana Paula Almeida

351 A aproximação da Arqueologia à sala de aula: um caso de estudo no $3^{\circ}$ ciclo do Ensino Básico Luís Serrão Gil

363 Arqueologia 3.o - Pensar e comunicar a Arqueologia para um futuro sustentável Mónica Rolo

377 “Conversa de Arqueólogos" - Divulgar a Arqueologia em tempos de Pandemia Diogo Teixeira Dias

389 Escola Profissional de Arqueologia: desafios e oportunidades Susana Nunes / Dulcineia Pinto / Júlia Silva / Ana Mascarenhas

399 Os Museus de Arqueologia e os Jovens: a oferta educativa para o público adolescente Beatriz Correia Barata / Leonor Medeiros

411 O museu universitário como mediador entre a ciência e a sociedade: o exemplo da secção de arqueologia no Museu de História Natural e da Ciência da Universidade do Porto (MHNC-UP)

Rita Gaspar 
421 Museu de Lanifícios: Real Fábrica de Panos. Atividades no âmbito da Arqueologia Beatriz Correia Barata / Rita Salvado

427 Arqueologia Pública e o caso da localidade da Mata (Torres Novas) Cláudia Manso / Ana Rita Ferreira / Cristiana Ferreira / Vanessa Cardoso Antunes

431 Do sítio arqueológico ao museu: um percurso (também) didático Lídia Fernandes

447 Estão todos convidados para a Festa! E para dançar também... O projecto do Serviço Educativo do Museu Arqueológico do Carmo na $5^{\underline{a}}$ Edição da Festa da Arqueologia Rita Pires dos Santos

459 O “Clã de Carenque”, um projeto didático de arqueologia Eduardo Gonzalez Rocha

469 Mediação cultural: peixe que puxa carroça nas Ruínas Romanas de Troia Inês Vaz Pinto / Ana Patrícia Magalhães / Patrícia Brum / Filipa Santos

481 Didática Arqueológica, experiências do Projeto Mértola Vila Museu Maria de Fátima Palma / Clara Rodrigues / Susana Gómez / Lígia Rafael

\section{Arte Rupestre}

497 Os inventários de arte rupestre em Portugal Mila Simões de Abreu

513 O projeto FIRST-ART - conservação, documentação e gestão das primeiras manifestações de arte rupestre no Sudoeste da Península Ibérica: as grutas do Escoural e Maltravieso Sara Garcês / Hipólito Collado / José Julio García Arranz / Luiz Oosterbeek / António Carlos Silva / Pierluigi Rosina / Hugo Gomes / Anabela Borralheiro Pereira / George Nash / Esmeralda Gomes / Nelson Almeida / Carlos Carpetudo

523 Trabalhos de documentação de arte paleolítica realizados no âmbito do projeto PalæoCôa André Tomás Santos / António Fernando Barbosa / Luís Luís / Marcelo Silvestre / Thierry Aubry

537 Imagens fantasmagóricas, silhuetas elusivas: as figuras humanas na arte do Paleolítico Superior da região do Côa Mário Reis

$55^{1}$ Os motivos zoomórficos representados nas placas de tear de Vila Nova de São Pedro (Azambuja, Portugal) Andrea Martins / César Neves / José M. Arnaud / Mariana Diniz

571 Arte Rupestre do Monte de Góios (Lanhelas, Caminha). Síntese dos resultados dos trabalhos efectuados em 2007-2009 Mário Varela Gomes

599 Gravuras rupestres de barquiformes no Monte de S. Romão, Guimarães, Noroeste de Portugal Daniela Cardoso

613 Círculos segmentados gravados na Bacia do Rio Lima (Noroeste de Portugal): contributos para o seu estudo Diogo Marinho / Ana M.S. Bettencourt / Hugo Aluai Sampaio

631 Equídeos gravados no curso inferior do Rio Mouro, Monção (NW Portugal). Análise preliminar Coutinho, L.M. / Bettencourt, A.M.S / Sampaio, Hugo A.S

645 Paletas na Arte Rupestre do Noroeste de Portugal. Inventário preliminar Bruna Sousa Afonso / Ana M. S. Bettencourt / Hugo A. Sampaio 


\section{Pré-História}

661 O projeto Miño/Minho: balanço de quatro anos de trabalhos arqueológicos Sérgio Monteiro-Rodrigues / João Pedro Cunha-Ribeiro / Eduardo Méndez-Quintas / Carlos Ferreira / Pedro Xavier / José Meireles / Alberto Gomes / Manuel Santonja / Alfredo Pérez-González

677 A ocupação paleolítica da margem esquerda do Baixo Minho: a indústria lítica do sítio de Pedreiras 2 (Monção, Portugal) e a sua integração no contexto regional Carlos Ferreira / João Pedro Cunha-Ribeiro / Sérgio Monteiro-Rodrigues / Eduardo Méndez-Quintas / Pedro Xavier / José Meireles / Alberto Gomes / Manuel Santonja / Alfredo Pérez-González

693 O sítio acheulense do Plistocénico médio da Gruta da Aroeira Joan Daura / Montserrat Sanz / Filipa Rodrigues / Pedro Souto / João Zilhão

703 As sociedades neandertais no Barlavento algarvio: modelos preditivos com recurso aos SIG

Daniela Maio

715 A utilização de quartzo durante o Paleolítico Superior no território dos vales dos rios Vouga e Côa

Cristina Gameiro / Thierry Aubry / Bárbara Costa / Sérgio Gomes / Luís Luís / Carmen Manzano / André Tomás Santos

733 Uma perspetiva diacrónica da ocupação do concheiro do Cabeço da Amoreira (Muge, Portugal) a partir da tecnologia lítica Joana Belmiro / João Cascalheira / Célia Gonçalves

745 Novos dados sobre a Pré-história Antiga no concelho de Palmela. A intervenção arqueológica no sítio do Poceirão I

Michelle Teixeira Santos

757 Problemas em torno de Datas Absolutas Pré-Históricas no Norte do Alentejo Jorge de Oliveira

771 Povoamento pré-histórico nas áreas montanhosas do NO de Portugal: o Abrigo 1 de Vale de Cerdeira Pedro Xavier / José Meireles / Carlos Alves

783 Apreciação do povoamento do Neolítico Inicial na Baixa Bacia do Douro. A Lavra I (Serra da Aboboreira) como caso de estudo Maria de Jesus Sanches

797 O Processo de Neolitização na Plataforma do Mondego: os dados do Sector C do Outeiro dos Castelos de Beijós (Carregal do Sal)

João Carlos de Senna-Martinez / José Manuel Quintã Ventura / Andreia Carvalho / Cíntia Maurício

823 Novos trabalhos na Lapa da Bugalheira (Almonda, Torres Novas) Filipa Rodrigues / Pedro Souto / Artur Ferreira / Alexandre Varanda / Luís Gomes / Helena Gomes / João Zilhão

837 A pedra polida e afeiçoada do sítio do Neolítico médio da Moita do Ourives (Benavente, Portugal)

César Neves

857 Casal do Outeiro (Encarnação, Mafra): novos contributos para o conhecimento do povoamento do Neolítico final na Península de Lisboa.

Cátia Delicado / Carlos Maneira e Costa / Marta Miranda / Ana Catarina Sousa

873 Stresse infantil, morbilidade e mortalidade no sítio arqueológico do Neolítico Final/ Calcolítico ( $4^{\circ}$ e $3^{\circ}$ milénio a.C.) do Monte do Carrascal 2 (Ferreira do Alentejo, Beja) Liliana Matias de Carvalho / Sofia N. Wasterlain 
885 Come together: O Conjunto Megalítico das Motas (Monção, Viana do Castelo) e as expressões Campaniformes do Alto Minho Ana Catarina Basílio / Rui Ramos

899 Trabalhos arqueológicos no sítio Calcolítico da Pedreira do Poio Carla Magalhães / João Muralha / Mário Reis / António Batarda Fernandes

913 O sítio arqueológico de Castanheiro do Vento. Da arquitectura do sítio à arquitectura de um território João Muralha Cardoso

925 Estudo zooarqueológico das faunas do Calcolítico final de Vila Nova de São Pedro (Azambuja, Portugal): Campanhas de 2017 e 2018 Cleia Detry / Ana Catarina Francisco / Mariana Diniz / Andrea Martins / César Neves / José Morais Arnaud

943 As faunas depositadas no Museu Arqueológico do Carmo provenientes de Vila Nova de São Pedro (Azambuja): as campanhas de 1937 a 1967 Ana Catarina Francisco / Cleia Detry / César Neves / Andrea Martins / Mariana Diniz / José Morais Arnaud

959 Análise funcional de material lítico em sílex do castro de Vila Nova de S. Pedro (Azambuja, Portugal): uma primeira abordagem Rafael Lima

971 O recinto da Folha do Ouro 1 (Serpa) no contexto dos recintos de fossos calcolíticos alentejanos

António Carlos Valera / Tiago do Pereiro / Pedro Valério / António M. Monge Soares

\section{Proto-História}

987 Produção de sal marinho na Idade do Bronze do noroeste Português. Alguns dados para uma reflexão

Ana M. S. Bettencourt / Sara Luz / Nuno Oliveira / Pedro P. Simões / Maria Isabel C. Alves / Emílio Abad-Vidal

1001 A estátua-menir do Pedrão ou de São Bartolomeu do Mar (Esposende, noroeste de Portugal) no contexto arqueológico da fachada costeira de entre os rios Neiva e Cávado Ana M. S. Bettencourt / Manuel Santos-Estévez / Pedro Pimenta Simões / Luís Gonçalves

1015 O Castro do Muro (Vandoma/Baltar, Paredes) - notas para uma biografia de ocupação da Idade do Bronze à Idade Média

Maria Antónia D. Silva / Ana M. S. Bettencourt / António Manuel S. P. Silva / Natália Félix

1031 Do Bronze Final à Idade Média - continuidades e hiatos na ocupação de Povoados em Oliveira de Azeméis João Tiago Tavares / Adriaan de Man

1041 As faunas do final da Idade do Bronze no Sul de Portugal: leituras desde o Outeiro do Circo (Beja)

Nelson J. Almeida / Íris Dias / Cleia Detry / Eduardo Porfírio / Miguel Serra

1055 A Espada do Monte das Oliveiras (Serpa) - uma arma do Bronze Pleno do Sudoeste Rui M. G. Monge Soares / Pedro Valério / Mariana Nabais / António M. Monge Soares

1065 São Julião da Branca (Albergaria-a-Velha) - Investigação e valorização de um povoado do Bronze Final

António Manuel S. P. Silva / Paulo A. P. Lemos / Sara Almeida e Silva / Edite Martins de Sá

1083 Do castro de S. João ao Mosteiro de Santa Clara: notícia de uma intervenção arqueológica, em Vila do Conde Rui Pinheiro 
1095 O castro de Ovil (Espinho), um quarto de século de investigação - resultados e questões em aberto

Jorge Fernando Salvador / António Manuel S. P. Silva

1111 O Castro de Salreu (Estarreja), um povoado proto-histórico no litoral do Entre Douro e Vouga

Sara Almeida e Silva / António Manuel S. P. Silva / Paulo A. P. Lemos / Edite Martins de Sá

1127 Castro de Nossa Senhora das Necessidades (Sernancelhe): uma primeira análise artefactual Telma Susana O. Ribeiro

${ }_{1141}$ A cividade de Bagunte. O estado atual da investigação Pedro Brochado de Almeida

1153 Zoomorfos na cerâmica da Idade do Ferro no NW Peninsular: inventário, cronologias e significado Nuno Oliveira / Cristina Seoane

1163 Vasos gregos em Portugal: diferentes maneiras de contar a história do intercâmbio cultural na Idade do Ferro

Daniela Ferreira

1175 Os exotica da necrópole da Idade do Ferro do Olival do Senhor dos Mártires (Alcácer do Sal) no seu contexto regional

Francisco B. Gomes

\section{Antiguidade Clássica e Tardia}

1191 O uso de madeira como combustível no sítio da Quinta de Crestelos (Baixo Sabor): da Idade do Ferro à Romanização Filipe Vaz / João Tereso / Sérgio Simões Pereira / José Sastre / Javier Larrazabal Galarza / Susana Cosme / José António Pereira / Israel Espi

1207 Cultivos de Época Romana no Baixo Sabor: continuidade em tempos de mudança? João Pedro Tereso / Sérgio Simões Pereira / Filipe Santos / Luís Seabra / Filipe Vaz

1221 A casa romana na Hispânia: aplicação dos modelos itálicos nas províncias ibéricas Fernanda Magalhães / Diego Machado / Manuela Martins

1235 As pinturas murais romanas da Rua General Sousa Machado, n. ${ }^{5}$ 1, Chaves José Carvalho

1243 Trás do Castelo (Vale de Mir, Pegarinhos, Alijó) - Uma exploração agrícola romana do Douro

Tony Silvino / Pedro Pereira

1255 A sequência de ocupação no quadrante sudeste de Bracara Augusta: as transformações de uma unidade doméstica Lara Fernandes / Manuela Martins

1263 Os Mosaicos com decoração geométrica e geométrico-vegetalista dos sítios arqueológicos da área do Conuentus Bracaraugustanus. Novas abordagens quanto à conservação, restauro, decoração e datação Maria de Fátima Abraços / Licínia Wrench

1277 “Casa Romana” do Castro de São Domingos (Cristelos, Lousada): Escavação, Estudo e Musealização Paulo André de P. Lemos

1291 A arqueobotânica no Castro de Guifões (Matosinhos, Noroeste de Portugal): O primeiro estudo carpológico

Luís Seabra / Andreia Arezes / Catarina Magalhães / José Varela / João Pedro Tereso 
1305 Um Horreum Augustano na Foz do Douro (Monte do Castelo de Gaia, Vila Nova de Gaia) Rui Ramos

1311 Ponderais romanos na Lusitânia: padrões, formas, materiais e contextos de utilização Diego Barrios Rodríguez

1323 Um almofariz centro-itálico na foz do Mondego

Marco Penajoia

1335 Estruturas romanas de Carnide - Lisboa Luísa Batalha / Mário Monteiro / Guilherme Cardoso

1347 O contexto funerário do sector da "necrópole NO" da Rua das Portas de S. Antão (Lisboa): o espaço, os artefactos, os indivíduos e a sua interconectividade na interpretação do passado Sílvia Loja, José Carlos Quaresma, Nelson Cabaço, Marina Lourenço, Sílvia Casimiro, Rodrigo Banha da Silva, Francisca Alves-Cardoso

${ }_{1361}$ Povoamento em época Romana na Amadora - resultados de um projeto pluridisciplinar Gisela Encarnação / Vanessa Dias

1371 A Arquitectura Residencial em Mirobriga (Santiago do Cacém): contributo a partir de um estudo de caso Filipe Sousa / Catarina Felício

${ }_{1385}$ O fim do ciclo. Saneamento e gestão de resíduos nos edifícios termais de Mirobriga (Santiago do Cacém)

Catarina Felício / Filipe Sousa

1399 Balsa, Topografia e Urbanismo de uma Cidade Portuária Vítor Silva Dias / João Pedro Bernardes / Celso Candeias / Cristina Tété Garcia

1413 No Largo das Mouras Velhas em Faro (2017): novas evidências da necrópole norte de Ossonoba e da sua ocupação medieval Ricardo Costeira da Silva / Paulo Botelho / Fernando Santos / Liliana Nunes

1429 Instrumentos de pesca recuperados numa fábrica de salga em Ossonoba (Faro) Inês Rasteiro / Ricardo Costeira da Silva / Paulo Botelho

1439 A Necrópole Romana do Eirô, Duas Igrejas (Penafiel): intervenção arqueológica de 2016 Laura Sousa / Teresa Soeiro

1457 Ritual, descarte ou afetividade? A presença de Canis lupus familiaris na Necrópole Noroeste de Olisipo (Lisboa)

Beatriz Calapez Santos / Sofia Simões Pereira / Rodrigo Banha da Silva / Sílvia Casimiro / Cleia Detry / Francisca Alves Cardoso

1467 Dinâmicas económicas em Bracara na Antiguidade Tardia Diego Machado / Manuela Martins / Fernanda Magalhães / Natália Botica

1479 Cerâmicas e Vidros da Antiguidade Tardia do Edifício sob a Igreja do Bom Jesus (Vila Nova de Gaia) Joaquim Filipe Ramos

1493 Novos contributos para a topografia histórica de Mértola no período romano e na Antiguidade Tardia Virgílio Lopes

\section{8. Época Medieval}

1511 Cerâmicas islâmicas no Garb setentrional "português": algumas evidências e incógnitas Constança dos Santos / Helena Catarino / Susana Gómez / Maria José Gonçalves / Isabel Inácio / Gonçalo Lopes / Jacinta Bugalhão / Sandra Cavaco / Jaquelina Covaneiro / Isabel Cristina Fernandes / Ana Sofia Gomes 
1525 Contributo para o conhecimento da cosmética islâmica, em Silves, durante a Idade Média Rosa Varela Gomes

1537 Yábura e o seu território - uma análise histórico-arqueológica de Évora entre os séculos VIII-XII José Rui Santos

1547 A encosta sul do Castelo de Palmela - resultados preliminares da escavação arqueológica Luís Filipe Pereira / Michelle Teixeira Santos

1559 A igreja de São Lourenço (Mouraria, Lisboa): um conjunto de silos e de cerâmica medieval islâmica

Andreia Filipa Moreira Rodrigues

1571 O registo material de movimentações populacionais no Médio Tejo, durante os séculos XII-XIII. Dois casos de "sunken featured buildings", nos concelhos de Cartaxo e Torres Novas Marco Liberato / Helena Santos / Nuno Santos

1585 O nordeste transmontano nos alvores da Idade média. Notas para reflexão Ana Maria da Costa Oliveira

1601 Sepulturas escavadas na rocha do Norte de Portugal e do Vale do Douro: primeiros resultados do Projecto SER-NPVD

Mário Jorge Barroca / César Guedes / Andreia Arezes / Ana Maria Oliveira

1619 "Portucalem Castrum Novum" entre o Mediterrâneo e o Atlântico: o estudo dos materiais cerâmicos alto-medievais do arqueossítio da rua de D. Hugo, nํ. 5 (Porto) João Luís Veloso

1627 A Alta Idade Média na fronteira de Lafões: notas preliminares sobre a Arqueologia no Concelho de Vouzela

Manuel Luís Real / Catarina Tente

1641 Um conjunto cerâmico medieval fora de portas: um breve testemunho aveirense Susana Temudo

${ }_{1651}$ Os Lóios do Porto: uma perspetiva integrada no panorama funerário da Baixa Idade Média à Época Moderna em meios urbanos em Portugal

Ana Lema Seabra

1659 O Caminho Português Interior de Santiago como eixo viário na Idade Média Pedro Azevedo

1665 Morfologia Urbana: Um exercício em torno do Castelo de Ourém André Donas-Botto / Jaqueline Pereira

1677 Intervenção arqueológica na Rua Marquês de Pombal/Largo do Espírito Santo (Bucelas, Loures)

Florbela Estêvão / Nathalie Antunes-Ferreira / Dário Ramos Neves / Inês Lisboa

1691 O Cemitério Medieval do Poço do Borratém e a espacialidade funerária na cidade de Lisboa Inês Belém / Vanessa Filipe / Vasco Noronha Vieira / Sónia Ferro / Rodrigo Banha da Silva

1705 Um Espaço Funerário Conventual do séc. XV em Lisboa: o caso do Convento de São Domingos da Cidade Sérgio Pedroso / Sílvia Casimiro / Rodrigo Banha da Silva / Francisca Alves Cardoso

\section{9. Época Moderna e Contemporânea}

1721 Arqueologia Moderna em Portugal: algumas reflexões críticas em torno da quantificação de conjuntos cerâmicos e suas inferências históricas e antropológicas Rodrigo Banha da Silva / André Bargão / Sara da Cruz Ferreira

1733 Faianças de dois contextos entre os finais do século XVI e XVIII do Palácio dos Condes de Penafiel, Lisboa

Martim Lopes / Tomás Mesquita 
1747 Um perfil de consumo do século XVIII na foz do Tejo: O caso do Mercado da Ribeira, Lisboa Sara da Cruz Ferreira / Rodrigo Banha da Silva / André Bargão

1761 Os Cachimbos dos Séculos XVII e XVIII do Palácio Mesquitela e Convento dos Inglesinhos (Lisboa)

Inês Simão / Marina Pinto / João Pimenta / Sara da Cruz Ferreira / André Bargão / Rodrigo Banha da Silva

1775 "Tomar os fumos da erua que chamão em Portugal erua sancta». Estudo de Cachimbos provenientes da Rua do Terreiro do Trigo, Lisboa

Miguel Martins de Sousa / José Pedro Henriques / Vanessa Galiza Filipe

1787 Cachimbos de Barro Caulínitico da Sé da Cidade Velha (República de Cabo Verde)

Rodrigo Banha da Silva / João Pimenta / Clementino Amaro

1801 Algumas considerações sobre espólio não cerâmico recuperado no Largo de Jesus (Lisboa) Carlos Boavida

1815 Adereços de vidro, dos séculos XVI-XVIII, procedentes do antigo Convento de Santana de Lisboa (anéis, braceletes e contas)

Joana Gonçalves / Rosa Varela Gomes / Mário Varela Gomes

1837 Da ostentação, luxo e poder à simplicidade do uso quotidiano: arqueologia e simbologia de joias e adornos da Idade Moderna Portuguesa Jéssica Iglésias

1849 Os amuletos em Portugal - dos objetos às superstições: o coral vermelho Alexandra Vieira

1865 Cerâmicas de Vila Franca de Xira nos séculos XV e XVI Eva Pires

1879 «Não passa por teu o que me pertence». Marcas de individualização associadas a faianças do Convento de Nossa Senhora de Aracoeli, Alcácer do Sal Catarina Parreira / Íris Fragoso / Miguel Martins de Sousa

1891 Cerâmica de Leiria: alguns focos de produção

Jaqueline Pereira / André Donas-Botto

1901 Os Fornos na Rua da Biquinha, em Óbidos Hugo Silva / Filipe Oliveira

1909 A casa de Pêro Fernandes, contador dos contos de D. Manuel I: o sítio arqueológico da Silha do Alferes, Seixal (século XVI) Mariana Nunes Ferreira

1921 O Alto da Vigia (Sintra) e a vigilância e defesa da costa Alexandre Gonçalves / Sandra Santos

1937 O contexto da torre sineira da Igreja de Santa Maria de Loures Paulo Calaveira / Martim Lopes

1949 A Necrópole do Hospital Militar do Castelo de São Jorge e as práticas funerárias na Lisboa de Época Moderna Susana Henriques / Liliana Matias de Carvalho / Ana Amarante / Sofia N. Wasterlain

1963 SAND - Sarilhos Grandes Entre dois Mundos: o adro da Igreja e a Paleobiologia dos ossos humanos recuperados

Paula Alves Pereira / Roger Lee Jesus / Bruno M. Magalhães

1975 Expansão urbana da vila de Cascais no século XVII e XVIII: a intervenção arqueológica na Rua da Vitória no 15 a 17

Tiago Pereira / Vanessa Filipe

1987 Novos dados para o conhecimento do Urbanismo de Faro em época Moderna Ana Rosa 
1995 Um exemplo de Arqueologia Urbana em Alcoutim: o Antigo Edifício dos CTT Marco Fernandes / Marta Dias / Alexandra Gradim / Virgílio Lopes / Susana Gómez Martínez

2007 Palácio dos Ferrazes (Rua das Flores/Rua da Vitória, Porto): a cocheira de Domingos Oliveira Maia

Francisco Raimundo

2021 As muitas vidas de um edifício urbano: História, Arqueologia e Antropologia no antigo Recreatório Paroquial de Penafiel Helena Bernardo / Jorge Sampaio / Marta Borges

2035 O convento de Nossa Senhora da Esperança de Ponta Delgada: o contributo da arqueologia para o conhecimento de um monumento identitário João Gonçalves Araújo / N’Zinga Oliveira

2047 Arqueologia na ilha do Corvo... em busca da capela de Nossa Senhora do Rosário Tânia Manuel Casimiro / José Luís Neto / Luís Borges / Pedro Parreira

2059 Perdidos à vista da Costa. Trabalhos arqueológicos subaquáticos na Barra do Tejo Jorge Freire / José Bettencourt / Augusto Salgado

2071 Arqueologia marítima em Cabo Verde: enquadramento e primeiros resultados do projecto CONCHA

José Bettencourt / Adilson Dias / Carlos Lima / Christelle Chouzenoux / Cristóvão Fonseca / Dúnia Pereira / Gonçalo Lopes / Inês Coelho / Jaylson Monteiro / José Lima / Maria Eugénia Alves / Patrícia Carvalho / Tiago Silva

2085 Trabalhos arqueológicos na Cidade Velha (Ribeira Grande de Santiago, Cabo Verde): reflexões sobre um projecto de investigação e divulgação patrimonial André Teixeira / Jaylson Monteiro / Mariana Mateus / Nireide Tavares / Cristovão Fonseca / Gonçalo C. Lopes / Joana Bento Torres / Dúnia Pereira / André Bargão / Aurélie Mayer / Bruno Zélie / Carlos Lima / Christelle Chouzenoux / Inês Henriques / Inês Pinto Coelho / José Lima / Patrícia Carvalho / Tiago Silva

2103 A antiga fortificação de Quelba / Khor Kalba (E.A.U.). Resultados de quatro campanhas de escavações, problemáticas e perspectivas futuras Rui Carita / Rosa Varela Gomes / Mário Varela Gomes / Kamyar Kamyad

2123 Colónias para homens novos: arqueologia da colonização agrária fascista no noroeste ibérico Xurxo Ayán Vila / José Mạ . Señorán Martín 


\title{
O CEMITÉRIO MEDIEVAL DO POÇO DO BORRATÉM E A ESPACIALIDADE FUNERÁRIA NA CIDADE DE LISBOA
}

\author{
Inês Belém ${ }^{1}$, Vanessa Filipe ${ }^{2}$, Vasco Noronha Vieira ${ }^{3}$, Sónia Ferro ${ }^{4}$, Rodrigo Banha da Silva ${ }^{5}$
}

\begin{abstract}
RESUMO
A intervenção arqueológica levada a cabo em 2018 na Rua do Poço do Borratém em Lisboa, permitiu identificar um segmento de espaço funerário com cronologias dos séculos XIII a XV, pelo registo de cerâmicas de importação. Este estudo pretende apresentar o contexto identificado e, posteriormente integrá-lo na espacialidade da cidade de Lisboa, compilando outros contextos funerários de cronologia medieval intervencionados na mesma. Procura-se, portanto, apresentar um estado da questão relativo a estes contextos, dada a importância da colaboração de vários elementos.

Palavras-Chave: Arqueologia Urbana, Arqueologia Funerária, Necrópole, Séculos XIII-XV.
\end{abstract}

\begin{abstract}
The archaeological intervention that took place in 2018 at Rua do Poço do Borratém in Lisbon allowed the identification of a funerary context with chronologies of the $13^{\text {th }}$ and $15^{\text {th }}$ centuries since imported ceramics were registered. This study intends to present the identified context and, later integrate it into the spatiality of the city of Lisbon compiling other funerary contexts of medieval chronology intervened. Therefore, it is intended to present a state of the question regarding these contexts given the importance of the collaboration of various elements.
\end{abstract}

Keywords: Urban Archaeology, Funerary Archaeology, Medieval Burial Grounds, $13^{\text {th }}-15^{\text {th }}$ centuries.

\section{INTRODUÇÃO}

O presente estudo diz respeito a uma etapa ainda inicial da investigação desenvolvida na sequência da intervenção arqueológica realizada em 2018 no Largo do Poço do Borratém, Santa Maria Maior, Lisboa, (Figura 1), localizada na via pública. Os trabalhos sucederam-se no âmbito de um projeto municipal de colocação de ecopontos subterrâneos no local, numa área da via publica, sendo da responsabilidade da empresa de arqueologia Cota 8o.86. Lda.

Procura-se, num primeiro momento, dar a conhecer o contexto identificado no Largo do Poço do Borratém no que diz respeito à sua realidade histórica e arqueológica envolvente, assim como os "elemen- tos datantes" exumados. Por fim, propõe-se enquadrar o contexto funerário na espacialidade da cidade medieval de Lisboa, através da compilação de dados de semelhante natureza e cronologia que foram intervencionados arqueologicamente na cidade. No presente artigo pretende-se, portanto, integrar os elementos exumados na sua conjuntura cronológica tendo em conta os dados arqueológicos identificados assim como, cartografá-los tendo como foco de interesse a espacialidade funerária da época. Todavia, a análise extensiva do conjunto exumado encontra-se ainda em curso aquando da redação do presente texto, pelo que aqui se avançam apenas alguns dados preliminares.

\footnotetext{
1. NOVA FCSH; inesbelemmota@gmail.com.

2. IAP - NOVA FCSH / Cota 80.86 Lda.; vanessagfilipe@gmail.com.

3. Cota8o.86 Lda.; vav@sapo.pt.

4. Universidade de Évora; barishi@hotmail.com.

5. CHAM - NOVA FCSH; UAç; CAL - DPC - CML; rodrigo.banha@cm-lisboa.pt.
} 
2. ALGUNS ELEMENTOS PRÉVIOS

À INTERVENÇÃO ARQUEOLÓGICA: SÍNTESE HISTÓRICA SOBRE A ERMIDA DE SÃO MATEUS

De acordo com a investigação histórica, o espaço funerário revelado pela intervenção arqueológica realizada na via pública do Largo do Poço do Borratém está conectado com a desaparecida Ermida de São Mateus (Figura 2), cuja edificação os historiadores de Lisboa situam entre a segunda metade do século XII e o século XIII, embora não exista consenso quanto à data concreta da sua fundação (Castilho, 1935; Correia, 1941; Sequeira, 1960; Silva, 2017). Erguida junto a uma das principais saídas setentrionais da cidade, que se dirigia à Mouraria, esta adotou uma importância estratégica como eixo de comunicação junto à Porta de São Vicente da Mouraria da Muralha Fernandina, cerca urbana edificada em 1373-75 (Silva \& Lourenço, 2019, p. 106).

A instituição da Ermida estará diretamente relacionada com a instalação de uma albergaria por Paio Delgado, que fora alegadamente participante em 1147 na conquista cristã de Lisboa. A albergaria associada à Ermida São Mateus tornar-se-ia numa das principais instituições assistenciais da cidade nos primeiros séculos de domínio português. Tendo como cabeça da instituição o templo dedicado a São Mateus (Castilho, 1935; Correia, 1941; Sequeira, 1960), a Albergaria manteve-se por herança no interior familiar, que se veio a constituir num dos principais núcleos da nobreza portuguesa e que lhe deve o seu nome, os Soares de Albergaria (Sequeira, 1960, p.7).

Em 1371, D. Fernando ordenou a extinção da albergaria, podendo nesta altura ter sido constituído o morgado de São Mateus. De Dona Catarina Dias, descendente do Bispo de Silves D. João Alão e filha de Lopo Soares de Albergaria, partidária de Dona Beatriz na crise de $1383-85$, passaram a D. Martim Vasques da Cunha, a quem D. João I a confisca pelas mesmas razões e acaba por doar o morgado ao seu genro, o famoso jurisconsulto João das Regras (Sequeira, 1960, p. 7), através de carta régia datada de 1392 (Castilho, 1935). Em consequência desta iniciativa régia, nos finais do século XIV, após receber o recém-constituído morgado de São Mateus, o Doutor João das Regras concedeu mercês a 20 merceeiras e constituiu no local da antiga albergaria a Mercearia de João das Regras (Correia, 1941;
Sequeira, 196o, p. 7), mais tarde alargada pelos Castro, Condes de Monsanto, a 30 beneficiárias (Sequeira, 1960, p. 10).

A fundação do Convento de São Domingos, em 1242, junto a uma outra via de saída da cidade de primeira ordem, iria a partir de D. Afonso III integrar nas suas hortas os terrenos que se estendiam entre o Rossio e os limites dos domínios do morgadio de São Mateus, que com ele estabeleceu uma relação de estreita vizinhança.

Em finais do século XV o morgado estava na posse do Conde de Monsanto, conforme o testemunho produzido em 1545 por Garcia de Resende relativo ao Hospital Real de Todos-Os-Santos: “(...) no anno de mil e quatrocentos e noventa e dous a quyinze dias do mes de Mayo mandou el-rey [D. João II] perante si fundar e começar os primeiros aliceces do esprital grande de Lixboa da invocaçam de Todolos Sanctos (...). E esse dia andou todo ahi vendo como se começava e comeo em casa do Conde de Monsanto que he pegada com a horta do dito esprital (Resende, 1596: cap. CXL). A Ermida permaneceria incorporada nos bens condais, embora sofrendo diversos usos temporários, incluindo no século XVII o conventual pelas Comendadeiras de S. Bento de Avis (Silva, 2017, p. 23), até à sua paulatina desaparição a partir da segunda metade do século XVIII, na sequência da reconstrução pombalina de Lisboa (Silva, 2017, p. 31).

\section{INTERVENÇÃO ARQUEOLÓGICA}

A realização de trabalhos de diagnóstico do potencial arqueológico na Rua do Poço do Borratém em 2018 dirigida por dois dos autores (VF, VNV) e desencadeada no âmbito de um projeto de instalação de ilha ecológica com seis ecopontos, resultou na abertura de uma sondagem de aproximadamente 30 $\mathrm{m}^{2}$. Desta ação resultou a identificação de um segmento de espaço funerário onde se registaram quatro níveis de enterramento e a respetiva sequência estratigráfica, demonstrando a importância científica deste contexto.

O espaço funerário da Baixa Idade Média viu a sua cronologia relativa aferida através do material cerâmico recolhido nos depósitos de enchimento das sepulturas e nos diversos níveis de pavimentos identificados, em particular os fragmentos de importação que integram os conjuntos. Ainda que insuficientemente divulgados, o seu registo noutros contextos 
lisboetas têm resultado em publicações deste tipo de produções oleiras forâneas, permitindo atribuir-se-lhes cronologias dos finais do século XIII a meados do século XV (Gaspar \& Amaro, 1997; Fernandes \& alii, 2008; Marques, 2015; Oliveira \& alii, 2017, 2017a; Silva, 2019; Silva \& alii, no prelo).

\subsection{Estratigrafia}

Numa fase inicial os trabalhos consistiram no acompanhamento da remoção com recurso a meios mecânicos das U.E.s [OO1],[OO2] e [oO2-A]. O primeiro horizonte de enterramentos foi identificado na U.E [019], equivalendo a 17 inumações em coval aberto num nível de pavimento em terra batida, cuja cronologia aponta para a primeira metade do século XV (Figura 3). Um segundo horizonte foi registado na U.E [086], revelando 12 sepulturas cobertas por um piso identificado como U.E [035], sendo-lhes atribuída preliminarmente uma baliza cronológica entre a segunda metade do século XIV e os inícios do século XV. Um terceiro horizonte, em que se reconheceram 14 sepulturas, foi registado como tendo sido abertas no piso identificado como U.E [135], apresentando uma datação inserida no século XIV. O último momento intervencionado diz respeito aos pisos U.Es [191] e [202], horizonte onde se procedeu ao registo de 18 sepulturas com cronologia do século XIV, sendo que se atingiu a cota máxima de afetação da obra. Esta circunstância implicou que nem todas as sepulturas tenham sido totalmente escavadas. Em síntese, foi identificado um total de 61 sepulturas distribuídas por 4 níveis estratigraficamente distintos de enterramento, das quais se levantaram 47 enterramentos e ossários, tendo ficado 22 sepulturas preservadas e por escavar, das quais 13 no plano final, e 9 nos perfis estratigráficos (Figura 4).

\subsection{Gestos funerários}

No contexto funerário registaram-se diversas formas de enterramento que se associam diretamente com a conjuntura social e cultural da cronologia de atribuição, em todo o caso homogeneamente enraizadas em matrizes cristãs. Deste modo, no perfil oeste, detetou-se uma estela discóide (Figura 5) elemento arquitetónico que estaria originalmente in situ e usado como pedra de cabeceira de uma sepultura com orientação O-E não intervencionada.

Os enterramentos e sepulturas identificadas correspondem maioritariamente a inumações primárias e enterramentos individuais (Duday \& alii, 2014, p. 237), sendo que os indivíduos se encontram em decúbito dorsal com os membros inferiores distendidos e os membros superiores fletidos sobre a zona do abdómen (Figura 4). Através da identificação de alguns fragmentos de alfinete aferiu-se que os enterramentos foram realizados com recurso a mortalha. Todavia, destacam-se exemplos de reduções associadas a inumações primárias, demonstrando a reutilização da sepultura. A forma de deposição e a orientação O-E refletem, portanto, a ideologia religiosa cristã, mostrando-se, pois, como deposições "canónicas". Não foi identificado espólio com associação direta ao gesto funerário, salvo raros vestígios de um fragmento de anel e pendente lítico.

\subsection{Espólio identificado e cronologia relativa da necrópole}

Os dados preliminares exumados na intervenção arqueológica que dizem respeito ao conjunto cerâmico provêm dos enchimentos das sepulturas e dos níveis de pavimento registados. O conjunto identificado em três dos quatros horizontes exumados apresenta uma diversidade de fabricos, demonstrando a existência de produções oriundas de centros hispânicos (Valencia e Sevilha), flamengos (de Bruges), do Norte de França (de Rouen e "Francês muito decorado") e da região de La Rochele, de Saintonge ("Saintonge Mottled" e "Saintonge Plain") (Figura 6).

A virtualidade destes fragmentos cerâmicos destaca-se uma vez que permitem atribuir propostas de datação para o contexto respectivo. Todavia só o estudo global do registo cerâmico, "fosco", pintado e vidrado, será passível de permitir atribuir balizas cronológicas mais finas.

As produções valencianas destacam-se pelas pastas granulosas, de fratura de tendência irregular com elementos de pequena e média dimensão. O vidrado é branco de estanho com pintura a azul, de cobalto, e a "dourado", de cobre. As produções sevilhanas apresentam pastas de cor amarelada, medianamente granulosas e de fratura irregular e com elementos muito bem distribuídos, recobertos por vidrado amarelado. Estes fabricos apresentam cronologias passíveis de se integrar nos séculos XIII a XV (Oliveira \& alii, 2017, pp. 1525-1526). Nos fabricos flamengos atribuídos a Bruges, produzidos entre os finais do século XIII e a primeira metade do século $\mathrm{XIV}$, destacam-se as características pastas avermelhadas homogéneas e compactas, por vezes bícromas vermelho-acinzentadas, sendo granulosas e de 
fratura irregular, com elementos bem distribuídos. O vidrado é espesso, de coloração verde, quase sempre manchado, em parte dos exemplares aplicado sobre um engobe branco espesso, sendo o interior dos recipientes desprovido de vidrado. As decorações típicas do fabrico de Bruges compreendem no caso faixas de motivos geométricos estampilhados ou produzidas mediante roletilha/carreto (Oliveira \& alii, 2017, p. 1528).

As produções do Norte de França e de Rouen tiveram uma ampla difusão em momentos bem avançados do século XIII e primeira metade do século XIV, sendo que apresentam pastas compactas de coloração branca e bege-acinzentada muito clara, com fratura nítida e textura granulosa com pequenos elementos bem distribuídos e de pequena dimensão, destacando-se escassos e esparsos elementos ferro-magnesianos de média dimensão. O vidrado apresenta uma primeira camada branca brilhante, sobre o qual se aplicou um outro laranja de tonalidade acastanhada, com motivo estampilhado em relevo recoberto a vidrado amarelo. O tipo "Francês do Norte muito decorado" apresenta pastas brancas, vidrados predominantemente verdes, de chumbo, ou verde mais claro, quando cobre foi adicionado (Oliveira \& alii, 2017, pp. 15271528). As produções de Saintonge representadas no Poço do Borratém materializam-se em pastas calcárias e cauliníticas, muito homogéneas e muito depuradas, de paredes delgadas, apresentando os vidrados verdes uma "transparência" vítrea, o mesmo verde "mosqueado de castanho" ("Saintonge mottled") ou liso ("Saintonge plain"). O vidrado permite formar uma superfície texturada, com tonalidades desde o verde esbranquiçado ao verde escuro (Oliveira \& alii, 2017, p. 1527).

A distribuição do limitado conjunto presente, numa primeira abordagem que é preliminar, demonstra maior expressão das produções do Norte de França no primeiro horizonte de enterramentos identificado, enquanto que as produções flamengas de Bruges e de Rouen apresentam uma expressão mais significativa no segundo e quarto horizontes exumados. As produções de Saintonge encontram-se igualmente representadas no primeiro e quarto horizontes. Já as produções hispânicas apresentam igual expressão no primeiro e segundo horizontes (Tabela 1).

\section{A ARQUEOLOGIA DE CONTEXTOS FUNERÁRIOS MEDIEVAIS EM LISBOA}

Arqueologicamente, o estudo da evolução da cidade de Lisboa envolve distintos métodos de pesquisa, onde convergem diferentes fontes (Fabião, 1994, p. 147). Assim, a cidade enquanto objeto de estudo justifica a abordagem arqueológica das relações entre as materialidades e os espaços urbanos, permitindo deste modo construir leituras do passado (Silva, 1999, p. 239). Convém recordar aqui que a cidade é um local heterotópico e, portanto, polissémica na sua diversidade, só se compondo a sua leitura global mediante o conhecimento das partes.

No que diz respeito especificamente aos contextos funerários, destaca-se o facto de abrangerem aspetos físicos, o meio ambiente e também a construção social, cultural e económica dentro do modus operandi de cada sociedade, pressupondo uma colaboração interdisciplinar (Pereira, 2018, p. 21). Ora, na inexistência para Lisboa de uma ideia ou conceito global programático de arqueologia da cidade como um todo, o conhecimento tem sido construído com base em dados fragmentários e dispersos, resultantes da aplicação de metodologias díspares e com qualidades de registo muito variáveis (Gaspar \& alii, 1997), sobretudo obtidos através de trabalhos de arqueologia preventiva, que dominam largamente o tipo de práticas da disciplina na cidade (Gaspar \& alii, 1997; Bugalhão, 2008). Neste mesmo sentido, e apesar de trabalhos académicos de folego já realizados sobre a arqueologia da morte em Lisboa (Nunes, 2010), falta ainda uma leitura integrada e multidisciplinar, que integre e agregue os conteúdos dos domínios mais tradicionalmente tratados por várias disciplinas, designadamente a epigrafia, a história da arte, a arqueologia e a bioantropologia.

Em referência a estas, a tumulária medieval portuguesa de Lisboa é rica, e nela se fazem representar, sobretudo, um conjunto de monumentos onde os programas iconográficos identificam o indivíduo, o grupo familiar e o ordenamento social a que pertencem, oferecendo representações heráldicas e/ou de cenas relacionadas com o caminho para o Além (Goulão, 1995; Barroca, 1997, p. 656), sendo de referenciar aqui os conjuntos da Sé (Fernandes, 2002), do Convento de São Domingos (Vale, 2003), Igreja de São Cristóvão (Matoso, 2001), Convento do Carmo e da desaparecida Igreja de Santo André, estes últimos conservados na Igreja da Graça. 
As estelas funerárias discóides são indissociáveis dos rituais funerários e das sepulturas, sendo que a orientação da sepultura com estela e com a deposição do individuo é muito comum a partir do séc. $\mathrm{XI}$, representando a orientação da igreja de Cristo voltada para nascente (Gomes \& Gomes, 2006, pp. 323-324). Incorporam, por isso, um domínio de especialidade que vem merecendo especial atenção nos domínios da história da arte e da arqueologia. Fazendo a denominação da estela discóide referência à sua forma circular ou em disco, que apresenta variantes morfológicas, com motivos gravados maioritariamente cruciformes, mas também geométricos, fitomórficos, epigráficos, heráldicos, de ofícios, zoomórficos e antropomórficos.

Os motivos cruciformes são os mais comuns nesta iconografia (incluindo variantes formais como a cruz templária, cruz grega, cruz pátea, ornamento cruciforme, cruz latina e cruz de tau) (Malveiro, 2017, p. 980), representando o símbolo cristão de identificação do defunto e não meramente um motivo decorativo (Viana, 1949, p. 85). Assim demonstra a conceção cristã da morte e o desejo simbólico do crente tendo em vista a ressurreição conforme o exemplo de Cristo (Malveiro, 2017, p. 982). Para o caso lisboeta, a quase totalidade dos exemplares estudados foi encontrado desprovido de contexto arqueológico, deste modo impedindo a articulação da informação associada.

A epigrafia fúnebre, que serviu como os elementos anteriores, para a permuta simbólica entre o visível e o invisível (a sepultura e o sepultado), assinalando a memória do falecido, bem como os seus atos, serviu como sinal/aviso para o não esquecimento do mesmo, eternizando o finito (Delgado, 2006, p. 515). Para o caso lisboeta a epigrafia foi objeto de estudo de Cordeiro de Sousa (1940), retomada e atualizada depois por Mário Barroca (1987), mas estando ainda em falta um estudo compreensivo de uma parte significante de textos funerários medievais mantidos inéditos.

No que se refere à bioantropologia, esta tem centrado o seu interesse em aspetos fundamentalmente biológicos. Ora, a necessidade de um contributo multidisciplinar no registo de campo e no processo de recolha de dados traduz-se numa abordagem que, para além de ser aplicada no momento da identificação dos vestígios osteológicos em campo, salvaguarda os fatores inerentes ao processo de decomposição do cadáver assim como a sua relação com a envol- vência (Cruz, 2011, pp. 13-14). Neste contexto desenvolvem-se os princípios metodológicos que recorrem ao registo rigoroso das deposições, ao estudo paleoantropológico dos restos humanos exumados e à análise das alterações dos vestígios osteológicos após a morte e deposição do cadáver (Marado \& alii, 2017, p. 1926). Deste modo, a compilação destes dados permite caracterizar o gesto funerário (Marado \& alii, 2017, p. 1926) reconstituindo práticas do passado (Stjerna, 2017, p. 447), fatores socioculturais, ideológicos, económicos, paleobiológicos, entre outros (Soares, 2019, p. 23).

Por fim, e em síntese, a arqueologia da morte em Lisboa, para além de outros interesses sectoriais já antes enunciados, ou dos óbvios aspetos de índole cronológica e/ou cultural, tem-se preocupado no essencial com as dinâmicas, arquiteturas e espaços tumulares.

Na realidade, quando se conduz um "inquérito" rápido produzido com base bibliográfica completada com o recurso ao Portal do Arqueólogo, consegue-se identificar/assinalar na cidade múltiplos contextos funerários medievais reconhecidos arqueologicamente (Figura 7), em contrapartida muito sumariamente publicados na sua quase totalidade e em nenhum caso integrando os dados das várias disciplinas. Assim, há a registar a exumação de sepultamentos medievais em quadros topológicos, sociais e culturais bastante diversificados, sintetizados em tabela (Tabela 2), que reflectem as distintas cronologias mas também, e sobretudo, as três dimensões religiosas da Lisboa Medieval, que encerram bem distintas formas de sepultamento, dado que o islamismo e o judaísmo "segregam" o morto de um ponto de vista urbanístico, ao passo que o cristianismo o integra na paisagem quotidiana da cidade dos vivos.

\section{CONSIDERAÇÕES FINAIS}

A temática da relação espacial dos cemitérios com o restante da malha urbana é uma relevante condição de leitura da própria cidade, dado o potente significado emocional da necrópole para as vivências da cidade viva (Mumford, 1961, p. 7). Em consequência, a influência das crenças religiosas no desenho urbano das cidades da Baixa Idade Média faz com que os preceitos espirituais guiem a forma como se tratam os mortos.

Pretendeu-se, portanto, facultar informação arqueológica recente, apresentando alguns dados prelimi- 
nares exumados no contexto funerário identificado no Poço do Borratém. Destes, os elementos cerâmicos atribuíveis a produções europeias com difusões relativamente bem balizadas cronologicamente, permitiram avançar com uma primeira proposta de datação para o conjunto do contexto respetivo. Deste modo, a presença de cerâmicas europeias de importação no horizonte 4 do Poço do Borratém (o mais antigo escavado) implica que se não possa atribuir-lhe uma cronologia mais recuada que os finais do século XIII, considerando aqui a baliza cronológica inferior daquelas cerâmicas; em contrapartida, convém aqui destacar a presença no horizonte 1 (o mais recente) de uma elaboração valenciana de "azul e dourado" (muito fragmentária para que se consiga discernir a gramática decorativa), tornando plausíveis, segundo o mesmo principio, estar-se perante cronologias que se não podem recuar dos finais do século XIV - século XV.

Para o caso do Poço do Borratém/Ermida de São Mateus, zona notoriamente envolvida em matéria de proximidade com um eixo de intensa circulação, assoma como significante a definição dos consecutivos quatro níveis funerários e as pavimentações associadas, sugerindo ações deliberadas e sucessivas que procuraram maximizar a capacidade do cemitério, mas no respeito dos anteriores inumados, um interessante contributo para o conhecimento do gesto funerário medieval de Lisboa.

\section{BIBLIOGRAFIA}

BARROCA, Mário (1987) - Necrópoles e sepulturas medievais de entre Douro e Minho. (Provas Públicas de Aptidão Pedagógica e Capacidade Científica). Porto: Faculdade de Letras da Universidade do Porto.

BARROCA, Mário (1997) - Cenas de passamento e de lamentação na escultura funerária medieval portuguesa: séc. XIII a XV. Revista da Faculdade de Letras. Porto: Universidade do Porto, pp. 655-684.

BATALHA, Luísa; NETO, Nuno; PEÇA, Pedro; BRITO, Sara; CARDOSO, Guilherme (2017) - Os silos do Palácio de Santa Helena (lisboa). In ARNAUD, José Morais; MARTINS, Andrea, eds. - Arqueologia em Portugal / 2017 - Estado da Questão. Lisboa: Associação dos Arqueólogos Portugueses, pp. 1751-1766.

BOAVENTURA, Inês (2016) - Que histórias têm para contar os 70 cadáveres encontrados junto à Sé de Lisboa?. Público. Disponível em [https://www.publico.pt/2016/10/31/ local/noticia/que-historias-tem-para-contar-os-7o-cadaveres-encontrados-junto-a-se-de-lisboa-1749229. Data da consulta: 07/2020].
BUGALHÃO, Jacinta (2008) - Lisboa e a sua Arqueologia: uma realidade em mudança. ERA Arqueologia. 8. Lisboa, pp. 218-230.

BUSOM, Júlia (2017) - Late Medieval Lisbon. Seven individuals from Praça da Figueira. (Dissertação de Mestrado). Cranfield: University of Cranfield (policopiado).

CASTILHO, Júlio (1935) - Lisboa Antiga: Bairros Orientais. III. Lisboa: S. Industriais da Câmara Municipal de Lisboa.

CORDEIRO DE SOUSA, J. (1940) - Inscrições Portuguesas de Lisboa (Séculos XII a XIX). Publicações Comemorativas do duplo centenário da fundação e restauração de Portugal. Lisboa: Academia Portuguesa da História.

CORREIA, Fernando (1941) - Os Velhos Hospitais da Lisboa Antiga. Revista Municipal. 11. Lisboa: Câmara Municipal de Lisboa, pp. 3-13.

CRUZ, Cristina (2011) - Viver a morte em Portugal: o potencial informativo dos relatórios antropológicos de campo (1994-2007). (Dissertação de Doutoramento) Coimbra: Universidade de Coimbra (policopiado).

CUNHA, Armando; FERREIRA, F. Rodrigues (1998) Vida e Morte na época de D. Afonso Henriques. Lisboa: Hugin Editores.

DELGADO, António (2006) - Estela, escultura e memória. Actas do VIII Congresso Internacional de Estelas Funerárias: Suplemento $n^{\circ} 3$ a O Arqueólogo Português, pp. 515-522.

DIOGO, A. M. Dias; TRINDADE, Laura (1999a) - Estudos Arqueológicos efetuados pelo G.T.T.R.L no Martim Moniz e a sua envolvente. Boletim do grupo "Amigos de Lisboa". II Série. 8, pp. 44-54.

DIOGO, A. M. Dias; TRINDADE, Laura (1999) - Inscrição funerária paleocristã da Rua de São Mamede ao Caldas, em Lisboa. Ficheiro epigráfico. 62, pp. 14-16.

DUDAY,Henri;LEMORT, Françoise; TILLIER, Anne-Marie (2014) - Archaeothanatology and funeral archaeology. Application to the study of primary single burial. Anthropologie. 3, pp. $235-246$.

FABIÃO, Carlos (1994) - Ler as Cidades Antigas: Arqueologia Urbana em Lisboa. Fazer e desfazer a História. 13, pp. 147-161.

FERNANDES, Carla Varela (2002) - Memórias de Pedra. Escultura Tumular Medieval da Sé de Lisboa. Lisboa: Ippar / Soc. Agric. Valle-Flôr/Tribunal Administrativo C

FERNANDES, L.; MARQUES, A.; TORRES, A. (2008) "Ocupação baixo medieval do teatro romano de Lisboa: a propósito de uma estrutura hidráulica, as cerâmicas vidradas e esmaltadas». In MACIAS, S., Coord. - Arqueologia Medieval. 10. Porto/Mértola: Afrontamento, pp. 159-184.

FILIPE, Vanessa; NETO, Nuno; HENRIQUES, José Pedro; BRITO, Sara; TOSO, Alice; CASIMIRO, Sílvia; GRANJA, Raquel; INOCÊNCIO, Joana; FERRO, Sónia (no prelo) - 
Espaços de uma cidade: novos dados sobre a necrópole islâmica de Lisboa Oriental. JORNADAS INTERNACIONAIS TERRA, PEDRAS E CACOS DO GARB AL-ANDALUS (Janeiro de 2020). Palmela.

FILIPE, Vanessa; TOSO, Alice; INOCÊNCIO, Joana (2017) - Perspectivas arqueo-biológicas sobre a necrópole islâmica de Alfama. I Encontro de Arqueologia de Lisboa: Uma Cidade em Escavação. Lisboa: Centro de Arqueologia de Lisboa, pp. 338-347.

GASPAR, Sara (2016) - Estudo dos indicadores de stresse e a sua relação com o contexto nutricional da coleção osteológica não-identificada do Castelo de São Jorge (século XI). (Dissertação de mestrado). Lisboa: Instituto Superior de Ciências Sociais e Políticas da Universidade de Lisboa (policopiado).

GOMES, M. V.; GOMES, R. V. (2006) - Estelas discóides da necrópole da Sé de Silves (Algarve, Portugal). Contexto e cronologia. Actas do VIII Congresso Internacional de Estelas Funerárias: Suplemento $n^{\circ} 3$ de O Arqueólogo Português, pp. 309-330.

GOULÃO, Maria José (1995) - Figuras do além: a escultura e a tumulária. In PEREIRA, Paulo, dir. - História da Arte Portuguesa: Temas e Debates. 2. Lisboa, pp. 157-179.

MALVEIRO, José (2017) - Estelas Funerárias Medievais do Distrito de Beja - Formas, suportes e iconografia. In ARNAUD, José Morais; MARTINS, Andrea, eds. - Arqueologia em Portugal / 2017-Estado da Questão. Lisboa: Associação dos Arqueólogos Portugueses, pp. 979- 986.

MARADO, Luís; FONTES, Luís; ANDRADE, Francisco; PEREIRA, Belisa (2017) - Arqueotanatologia moderna/ contemporânea: práticas funerárias e cronologia relativa no adro da Igreja de Santa Maria dos Anjos, Valença. In ARNAUD, José Morais; MARTINS, Andrea, eds. - Arqueologia em Portugal / 2017 - Estado da Questão. Lisboa: Associação dos Arqueólogos Portugueses, pp. 1925-1932.

MARQUES, António Augusto (2015) - Jarro decorado: Pichel decorado com vieiras e cachos. In TEIXEIRA, A.; VILLADA PAREDES, F.; SILVA, R.B., eds. - Lisboa 1415 Ceuta: História de dos Ciudades. Ceuta: Ciudad Autónoma de Ceuta e Câmara Municipal de Lisboa, pp. 178-18o.

MARQUES, António; BASTOS, Margarida (2017) - Subsídios arqueológicos para a História da Igreja do Convento do Carmo (Lisboa). In ARNAUD, José Morais; MARTINS, Andrea, eds. - Arqueologia em Portugal/2017 - Estado da Questão. Lisboa: Associação dos Arqueólogos Portugueses, pp. 1091-1101.

MATOSO, Inês (2001) - Um apontamento de Tumulária Medieval: O Conjunto da Igreja de São Cristóvão em Lisboa. Arqueologia e História. 53. Lisboa: Associação dos Arqueólogos Portugueses, pp. 75-9o.

MUMFORD, Lewis (1961) - The City in History: Its Origins, Its Transformations, and Its Prospects. Nova Iorque: Harcourt, Brace \& World.
NUNES, Maria Margarida Athaíde (2010) - A morte em Lisboa na Idade Média. Contributo arqueológico (séculos XII a $X V)$. (Dissertação de Doutoramento) Lisboa: Faculdade de Ciências Sociais e Humanas da Universidade Nova de Lisboa (Policopiado).

OLIVEIRA, Filipe; MIGUEZ, João; FURTADO, Catarina; COSTA, Cláudia (2017a) - Caracterização da Ocupação Tardomedieval na Rua da Prata 221-231 e Rua dos Correeiros 158-168, Lisboa. In ARNAUD, José Morais; MARTINS, Andrea, eds. - Arqueologia em Portugal/2017 - Estado da Questão. Lisboa: Associação dos Arqueólogos Portugueses, pp. 1567-1580.

OLIVEIRA, Filipe; SILVA, Rodrigo Banha da; BARGÃO, André; FERREIRA, Sara (2017) - O comércio medieval de cerâmicas importadas em Lisboa: o caso da Rua das Pedras Negras n‥ 21-28. In ARNAUD, José Morais; MARTINS, Andrea, eds. - Arqueologia em Portugal / 2017 - Estado da Questão. Lisboa: Associação dos Arqueólogos Portugueses, pp. 1523-1538.

PEDROSO, Sérgio (2020) - Restos Humanos em Coleções e Museus: questões éticas e Legais: o caso de uma possível comunidade judaica em Alfama. (Trabalho académico realizado no âmbito do Seminário de Mestrado de Arqueologia da Morte). Lisboa: Faculdade de Ciências Sociais e Humanas da Universidade Nova de Lisboa.

PEREIRA, Verónica (2018) - A Espacialidade da Morte na Lisboa Moderna: Contributos para uma Arqueologia Funerária na Igreja de São Lourenço, Mouraria. (Dissertação de Mestrado). Lisboa: Faculdade de Ciências Sociais e Humanas da Universidade Nova de Lisboa (policopiado).

PONCE, Mónica; OLIVEIRA, Filipe; NUNES, Tiago; PINTO, Marina; LOURENÇO, Marina (2017) - O sítio dos Lagares (Lisboa): um espaço pluricultu(r)al. In ARNAUD, José Morais; MARTINS, Andrea, eds. - Arqueologia em Portugal/2017 - Estado da Questão. Lisboa: Associação dos Arqueólogos Portugueses, pp. 1703-1714.

RESENDE, Garcia de (1596) - Chronica que tracta da vida e grandíssimas virtudes [...] de Dom João o Segundo. Lisboa: Casa de Simão Lopez.

RODRIGUES, Jorge (2016) - A Sé de Lisboa, de panteão régio de $\mathrm{D}$. Afonso IV a necrópole de enterramentos privilegiados no final da Idade Média. In MELO, Joana; AFONSO, Luís, eds. - O Fascínio do Gótico. Um tributo a José Custódio Vieira da Silva. Lisboa: Instituto de História da Arte da Faculdade de Letras da Universidade de Lisboa, pp. 33-52.

SEQUEIRA, Matos (1960) - Uma viagem à roda da Praça da Figueira. Revista Municipal. 86. Lisboa: Câmara Municipal de Lisboa.

SERAFIM, Inês (2017) - Análise biocultural de indivíduos exumados do Mosteiro de São Vicente de Fora (Lisboa). (Dissertação de Mestrado). Coimbra: Faculdade de Ciências e Tecnologias da Universidade de Coimbra (policopiado). 
SILVA, André (2019) - As cerâmicas medievais dos antigos Armazéns Sommer, em Lisboa (Sécs. XIII-XIV). (Dissertação de Mestrado). Lisboa: Faculdade de Ciências Sociais e Humanas da Universidade Nova de Lisboa (policopiado).

SILVA, André Martins (2017) - O Convento da Encarnação das Comendadeiras de São Bento de Avis. Cadernos Culturais - Telheiras - Lumiar - Olivais. 2 $2^{\underline{a}}$ Série. 10 (Novembro 2017). Lisboa: Centro Cultural Eça de Queiroz, pp. 17-33.

SILVA, Hélia; LOURENÇO, Tiago (2019) - A Ilha. História e urbanismo do grande quarteirão onde se implantou o Hospital Real de Todos-os-Santos, ao Rossio (1750-1779). Cadernos do arquivo municipal. 2ª̂ série. 11. Lisboa, pp.103-126.

SILVA, Rodrigo Banha da (1999) - Conceções de Arqueologia Urbana em Lisboa. III Colóquio Temático Lisboa - Utopia na viragem do milénio. Lisboa: Fórum Lisboa - Edifício Roma, pp. 229-240.

SILVA, Rodrigo Banha da (2018) - O Convento de São Domingos, em Lisboa, e a leitura arqueológica das suas hortas, entre os séculos XIII e XV. In ANDRADE, Amélia Aguiar; TENTE, Catarina; SILVA, Gonçalo Melo da; PRATA, Sara, eds. - Espaços e poderes na Europa urbana medieval. Castelo de Vide: IEM/FCSH/NOVA, Câmara Municipal de Castelo de Vide (col. Estudos, 18), 2018, pp. 553-569.
SILVA, Rodrigo Banha da; BARGÃO, André; FERREIRA, Sara; TORRES, Joana Bento; TEIXEIRA, André (no prelo) - Um contexto cerâmico da Baixa Idade Média da Rua dos Correeiros (Baixa de Lisboa): revisão crítica dos dados da sondagem 24-1991. Actas do II Encontro de Arqueologia de Lisboa. Lisboa: Centro de Arqueologia de Lisboa, pp. 258-278.

SOARES (2019) - Análise de indivíduos da necrópole medieval-moderna da Igreja Matriz de São Salvador (Sines): raízes africanas entre o povo português. (Dissertação de Mestrado). Coimbra: Universidade de Coimbra (policopiado).

STJERNA, Rita (2017) - Arqueotanatologia e coleções museológicas: estratégias e desafios para o estudo das práticas funerárias do passado. In ARNAUD, José Morais; MARTINS, Andrea, eds. - Arqueologia em Portugal / 2017 - Estado da Questão. Lisboa: Associação dos Arqueólogos Portugueses, pp. 447-459.

VALE, Teresa Leonor M. (2003) - Breve percurso pela tumulária do antigo Convento de S. Domingos de Benfica, Lisboa: abordagem de alguns exemplares relevantes. Olisipo: Boletim do Grupo Amigos de Lisboa. Série 2. 18. Lisboa, pp. 18-30.

VIANA, Abel (1949) - Estelas discóides do Museu de Beja. Arquivo de Beja. VI, pp. 37-85.

\begin{tabular}{|c|c|c|c|c|c|c|c|c|c|}
\hline & & \multicolumn{8}{|c|}{ Produção } \\
\hline Horizonte & U.E. & Bruges & Paris - Rouen & Norte de França muito decorado & Saintonge "mottled" & Saintonge "Plain" & Norte de França? & Valencia & Sevilha \\
\hline I & [019] & 2 & & & & & & & \\
\hline I & [029] & 2 & & & & & & & \\
\hline $\mathrm{I}$ & [035] & 2 & & & & & & & \\
\hline I & [051] & 1 & & 1 & & & & & \\
\hline $\mathrm{I}$ & [053] & 1 & 1 & & & 1 & 2 & 1 & \\
\hline I & [059] & 1 & & & & & & & \\
\hline II & [086] & 8 & 1 & & & & & & 1 \\
\hline IV & [191] & 7 & 2 & & 1 & & 1 & & \\
\hline \multicolumn{2}{|l|}{ Total } & 24 & 4 & 1 & 1 & 1 & 1 & 1 & 1 \\
\hline
\end{tabular}

Tabela 1 - Distribuição dos fragmentos cerâmicos de importação nos horizontes identificados. 


\begin{tabular}{|c|c|c|c|c|c|c|c|c|c|c|}
\hline N.: & Designaçào & $\begin{array}{l}\text { Espace } \\
\text { Urbano }\end{array}$ & CNS & I.A.C. & $\begin{array}{c}\text { No de } \\
\text { sepulturas }\end{array}$ & Ritual & Zona & $\begin{array}{c}\text { Datacào } \\
\text { Atribuida }\end{array}$ & Observaçies & Bibliografia \\
\hline 1 & Igreja do Santissimo Sacramento & Paroquial & 3503 & 1990 & 2 & Cristlo & Nave & năo def. & $\begin{array}{l}\text { Enterramentos praticados sobre fragmentos } \\
\text { de tellha e tijoleira }\end{array}$ & \begin{tabular}{|l|} 
Nunes, 2010, p.219 \\
\end{tabular} \\
\hline 2 & $\begin{array}{l}\text { Igreja de Såo Mamede (Rua de S. Mamede ao } \\
\text { Caldas. VP) }\end{array}$ & Paroquial & 16063 & 1993 & 1 & Cristato & Adro & XII-XIII & $\begin{array}{l}\text { Enterramento em coval, cobertura pétrea, de } \\
\text { elementos arquitetónicos e epigrifíco do sece. } \\
\text { VI reaproveitados }\end{array}$ & $\begin{array}{l}\text { Diogo \& Trindade, } \\
\text { 1999: Nunes, 2010, p. } \\
119 \text {. }\end{array}$ \\
\hline 3 & Convento do Salvador & \begin{tabular}{|l} 
Conventual \\
\end{tabular} & 35359 & $1960 ; 2008$ & $>10$ & Cristâo & Nave e Adro & $\begin{array}{l}>\text { XIII e > } \\
1391\end{array}$ & \begin{tabular}{|l|} 
Caixa com lípide sepulcral (nave); \\
enterramentos e ossarios; estelas discóides e \\
tampa de sarcofagog (adro a sul)
\end{tabular} & $\begin{array}{l}\text { Nunes, 2010, p. 262- } \\
263 ; \text { PA }\end{array}$ \\
\hline $4 ; 5$ & $\begin{array}{l}\text { Igreja e Convento de S. Domingos (Largo de S. } \\
\text { Domingos e Praça da Figueira) }\end{array}$ & \begin{tabular}{|l} 
Conventual \\
\end{tabular} & $\begin{array}{l}6187 / 19 \\
25\end{array}$ & $\begin{array}{l}1991 ; 1999- \\
2001\end{array}$ & $>12$ & Cristao & Adro e Cerca & $\begin{array}{l}>1242 \mathrm{e} \\
\mathrm{XV}\end{array}$ & \begin{tabular}{|l|}
12 sepulturas em coval, mas com \\
enterramentos múttiplos (adro); 10 sepulturas \\
individuais em coval (cerca)
\end{tabular} & \begin{tabular}{|l|} 
Diogo e c Trindade, \\
1999, p.50: Busom, \\
2017; Silva, 2018
\end{tabular} \\
\hline 6 & Largo da Graca & Conventual & 36818 & Sem inf. & nalo def. & Cristato & Cerca & XIV? & Enterramentos em coval & Nunes, 2010 , p. 132 \\
\hline 7 & Praça Nova do Castelo de S. Jorge & Almocivar & 1101 & 1997-2007 & 14 & Islâmico & Junto à Mesquita & XII & $\begin{array}{l}\text { Enterramentos sm coval, um infantil coberno } \\
\text { por telhas curvas; lápide funcriaria inscrita }\end{array}$ & Gaspar, 2016, p. 29 \\
\hline 8 & Castelo de S. Jorge - Palácio das Cozinhas & $\begin{array}{l}\text { Almocévar; } \\
\text { Capela }\end{array}$ & 13306 & 1997-2007 & $20 ; 1$ & \begin{tabular}{|l|} 
Islâmico \\
Criståo
\end{tabular} & $\begin{array}{l}\text { Proximidade da Capela de } \\
\text { S. Miguel do Paço Real da } \\
\text { Alcácova }\end{array}$ & $\mathrm{XII} ; \mathrm{XV}$ ? & Enterramentos em coval; estela discóide & Gaspar, 2016, p. 29 \\
\hline 9 & $\begin{array}{l}\text { Castelo de Săo Jorge - Igreja de Santa Cruz } \\
\text { (Largo de Santa Cruz) }\end{array}$ & Paroquial & 36195 & 2001 & nào def. & Cristlo & Adro & XII-XVI & Enterramentos en coval; estela discóide & P.A. \\
\hline 10 & Igreja de Såo Martinlło & Paroquial & 22646 & 2005 & $\begin{array}{l}25 \mathrm{sep} \\
5 \text { oss }\end{array}$ & Cristato & Adro & XII-XVI & Enterramentos intensivos $\mathrm{em}$ coval; ossários & Nuncs, 2010, p. 169 \\
\hline 11 & $\begin{array}{l}\text { Igreja de Santa Maria de Alcamim; Sào } \\
\text { Cristovido }\end{array}$ & Paroquial & 22557 & 2004 & 1 & Cristlo & Adro & $>\mathrm{XII}$ & $\begin{array}{l}\text { Enterramento in situ com restos osteológicos } \\
\text { de dois individuos }\end{array}$ & Nunes, 2010, p. 136 \\
\hline 12 & Se e Cruzes da Sé & Catedral & $\begin{array}{l}3229, \\
36271\end{array}$ & c. $1940: 2016$ & $>70$ & Cristao & Adro a sul & $>1 / 2$ XII & $\begin{array}{l}\text { Sarcofagos; estelas discóides; enterramentos } \\
\text { me coval }\end{array}$ & $\begin{array}{l}\text { Boaventura, 2016; } \\
\text { Sousa 1940 }\end{array}$ \\
\hline 13 & Igreja e Convento do Carmo & \begin{tabular}{|l|} 
Conventual \\
\end{tabular} & 3996 & $\begin{array}{l}2008 ; 2010- \\
2011\end{array}$ & 41 & Cristlo & Adro a oeste e a sul & $>\mathrm{XV}$ & Enterramentos em coval & $\begin{array}{l}\text { Marques e Bastos, } \\
\text { 2017, p.1091 }\end{array}$ \\
\hline 14 & Mosteiro de Sảo Vicente & Conventual & 1453 & $\begin{array}{l}\text { 1982: 1987/89; } \\
\text { 1992; 1993/94; } \\
1997\end{array}$ & $\begin{array}{l}\text { 14: } \\
2 ; 9 ; 9 ; 2 ; 1\end{array}$ & Cristäo & $\begin{array}{l}\text { Ossário; Cerca } \\
\text { Conventual, Sacrário }\end{array}$ & $>\mathrm{XII}$ & Ossário; enterramentos $\mathrm{em}$ coval & $\begin{array}{l}\text { Cunhla \& Ferreira, } \\
1998 \text {; Serafim, 2017; } \\
\text { Nunes, 2010, pp. 148 . } \\
159\end{array}$ \\
\hline 15 & Judiaria Pequena - Rua de S. Miguel, Alfama & ? & nào def. & $2005-2006$ & $>5$ & \begin{tabular}{|l|l|l} 
Judaico? \\
\end{tabular} & Proximidade da Sinagoga & XIII-XV & $\begin{array}{l}\begin{array}{l}\text { Coval, com nivel de carneiro e uma sepultura } \\
\text { de inumaçâ }\end{array} \\
\end{array}$ & Pedroso, 2020 \\
\hline 16 & "Almocávar Grande" (Rua dos Lagares n $\left.n^{\circ} 74\right)$ & Almocávar & 36216 & $2015 / 2015$ & 335 & \begin{tabular}{|l|} 
Islâmico \\
Judaico
\end{tabular} & $\begin{array}{l}\text { Meia encosta do Monte de } \\
\text { S. Gens }\end{array}$ & $\begin{array}{l}\mathrm{XVI} \mathrm{e}^{<} \\
\mathrm{XVI}\end{array}$ & $\begin{array}{l}\text { I fases distintas - islâmica do século XVI e } \\
\text { judaica }\end{array}$ & $\begin{array}{l}\text { Ponce \& alti, 2017, } \\
\text { p. } 1703-1703\end{array}$ \\
\hline 17 & $\begin{array}{l}\text { Rua dos Lagares } n^{\circ} 24 \text { - Necróppole do } \\
\text { Ouarteirấo dos Lagares }\end{array}$ & \begin{tabular}{|l|l|} 
Almocávar \\
\end{tabular} & 35576 & 2013 & 7 & Islâmico & $\begin{array}{l}\text { Meia encosta do Monte de } \\
\text { S. Gens }\end{array}$ & nảo def. & Enterramentos em coval & $\mathrm{PA}$ \\
\hline 18 & Almocávar (Palácio de Santa Helena) & Almocávar & 36335 & 2016 & 19 & Islâmico & Morro a oriente de Alfarna & $\begin{array}{l}<\text { fim do } \\
\text { XIII }\end{array}$ & Enterramentos em coval & $\begin{array}{l}\text { Batalha \& alii, } 2017 . \\
\text { p.1752 }\end{array}$ \\
\hline 19 & Almocivar (Largo de Santa Marinha) & Almocávar & 35347 & $2018-2019$ & $>10$ & \begin{tabular}{|l|l|l} 
Islâmico \\
\end{tabular} & $\begin{array}{l}\text { Encosta do morro a oriente } \\
\text { de Alfama }\end{array}$ & $<\mathrm{XII}$ & Enterramentos em coval; ossário & Filipe \& alii, no prelo \\
\hline 20 & Igreja de Săo Lourenço & Paroquial & 13789 & 1992-93: & $>39$ & Cristao & $\begin{array}{l}\text { Nave; Capela gótica; } \\
\text { Antiga casa do guarda }\end{array}$ & $>$ XIII & al: ossários: & $\begin{array}{l}\text { Nunes, 2010, pp. } 172 \text { - } \\
174\end{array}$ \\
\hline 21 & Calçadinha do Tijolo no $37-43$ & Almocívar & 35347 & 2014 & 5 & Islâmico & Merro a oriente de Alfarma & $<\mathrm{XIII}$ & Enterramentos em coval & $\begin{array}{l}\text { Filipe \& alii, 2017, } \\
\text { pp.338-347 }\end{array}$ \\
\hline
\end{tabular}

Tabela 2 - Compilação de contextos funerários medievais identificados e intervencionados arqueologicamente em Lisboa.

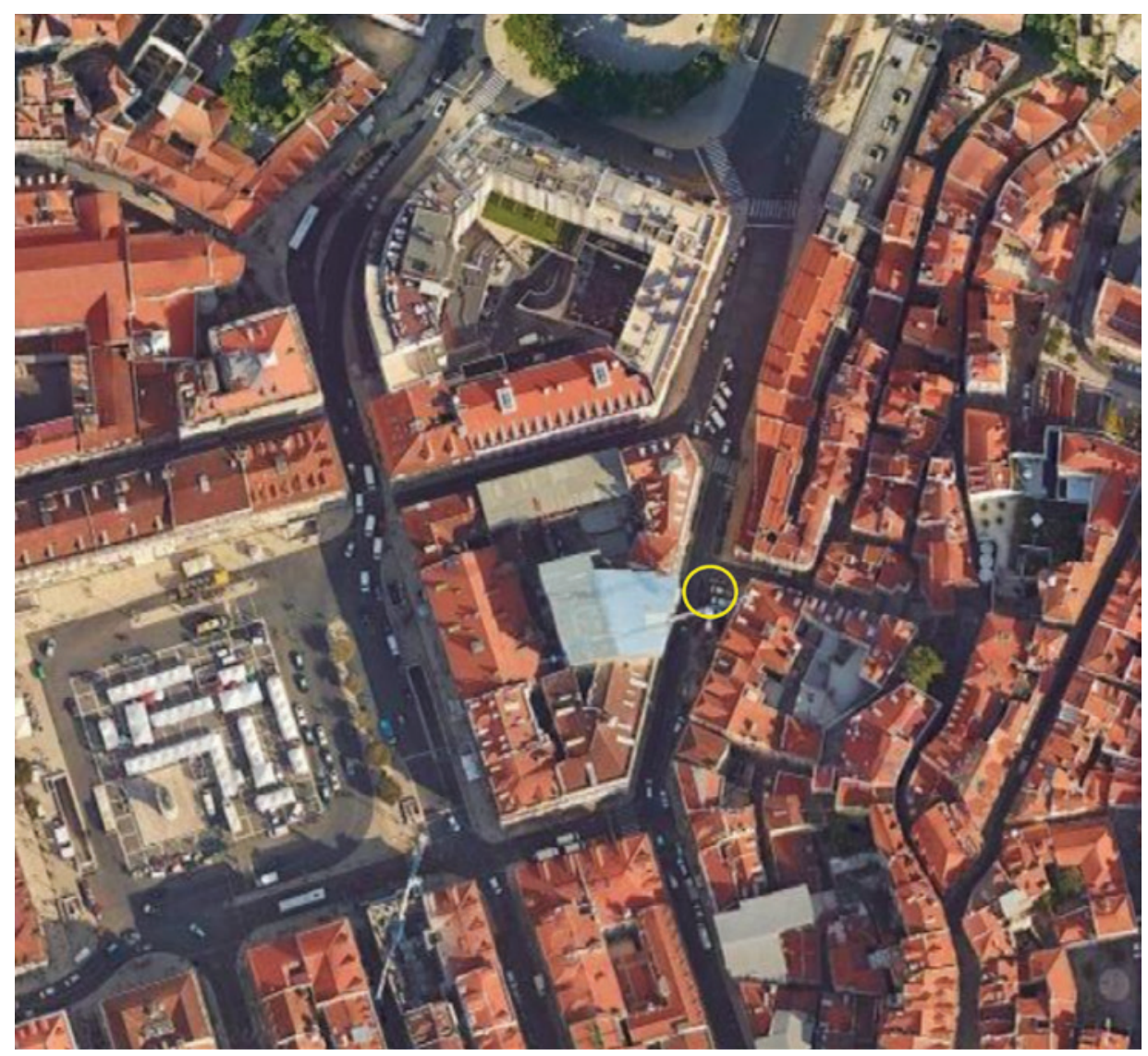

Figura 1 - Localização da intervenção arqueológica no Poço do Borratém. Fonte: Google Maps. 


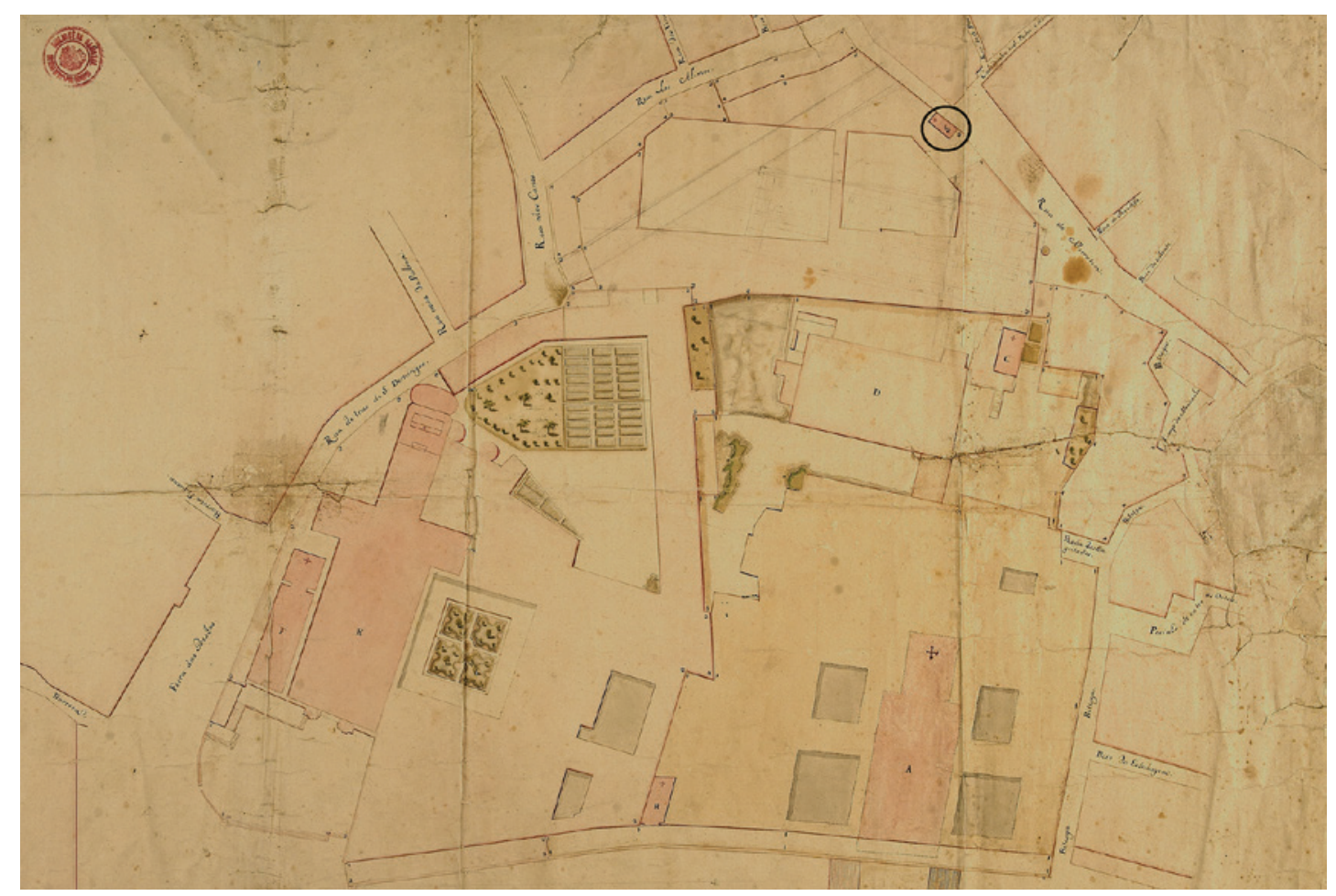

Figura 2 - Localização da Ermida de São Mateus na Planta Topográfica que compreende a Ilha em que estava edificado o Hospital Real de Todos os Santos do Ill.Mo e Exm.o Marquês de Cascaes, Guilherme J. Paes de Menezes e Tomás Roiz da Costa, 175o. Disponível em Biblioteca Nacional Digital [http://purl. pt/22488. Data da consulta: 07/2020].

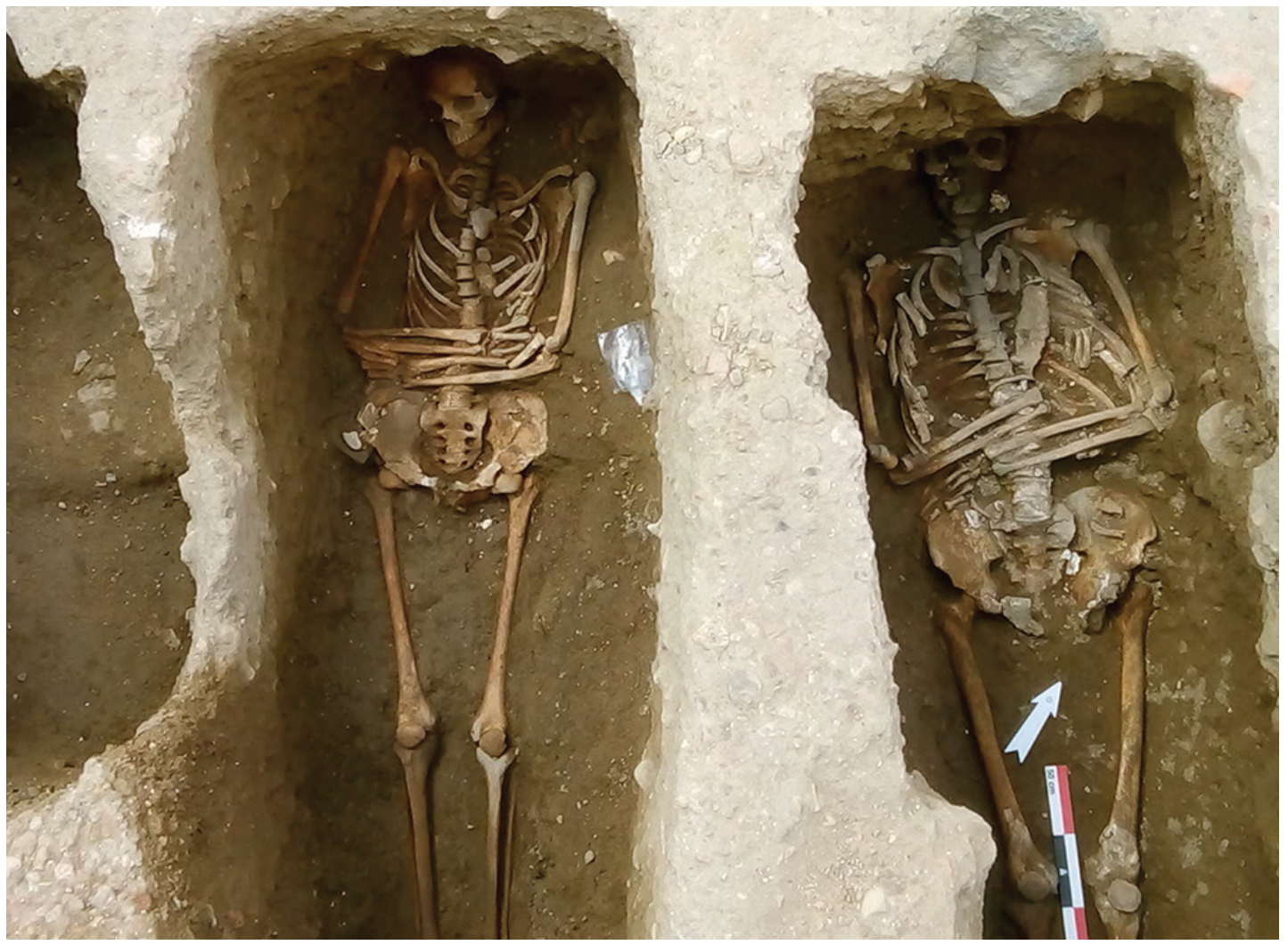

Figura 3 - Vista de um segmento do primeiro horizonte de enterramentos identificado. 


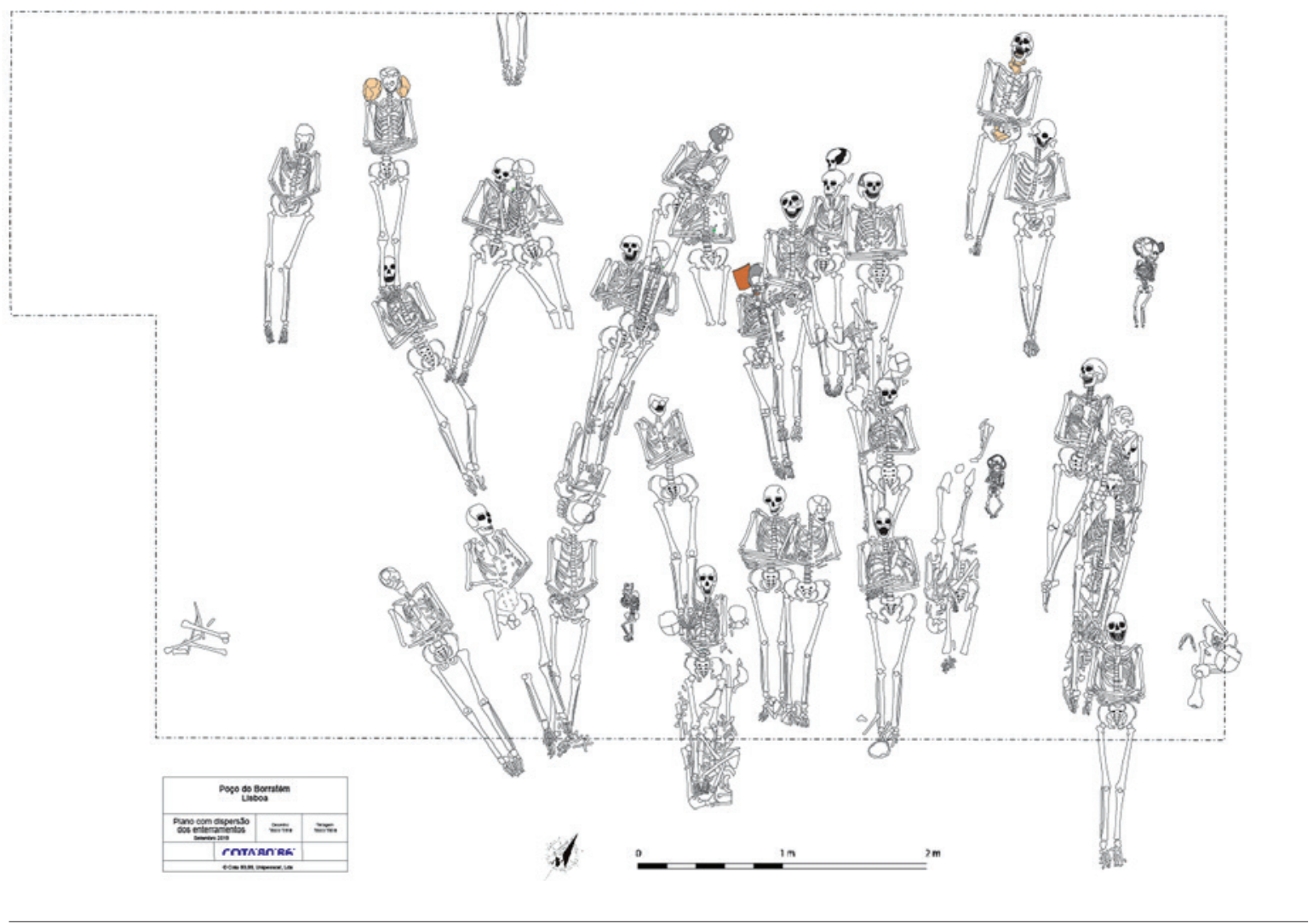

Figura 4 - Planta da distribuição dos enterramentos identificados no Poço do Borratém.

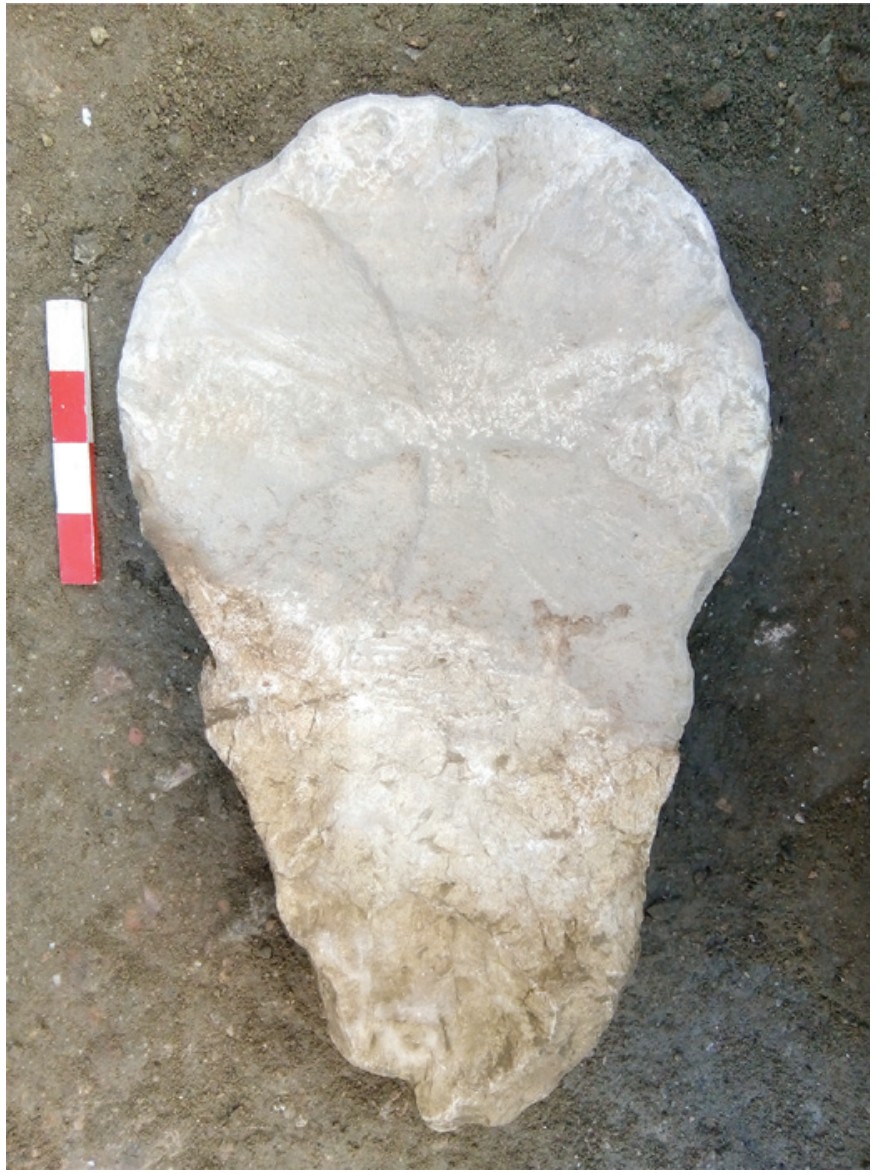

Figura 5 - Estela discoide identificada na intervenção arqueológica do Poço do Borratém. 


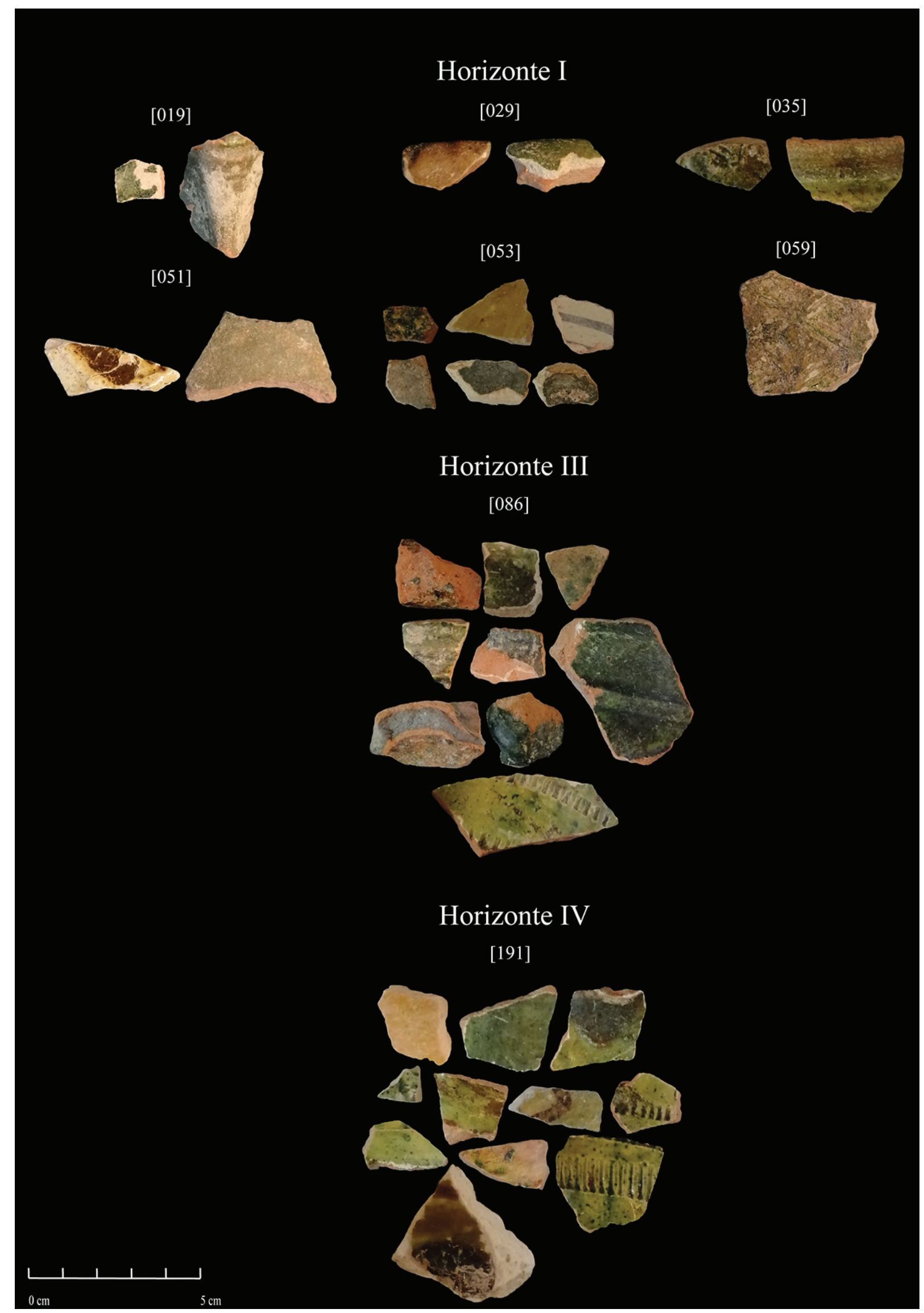

Figura 6 - Estampa dos fragmentos cerâmicos de importação exumados de três dos quatro horizontes de enterramentos identificados no Poço do Borratém. 


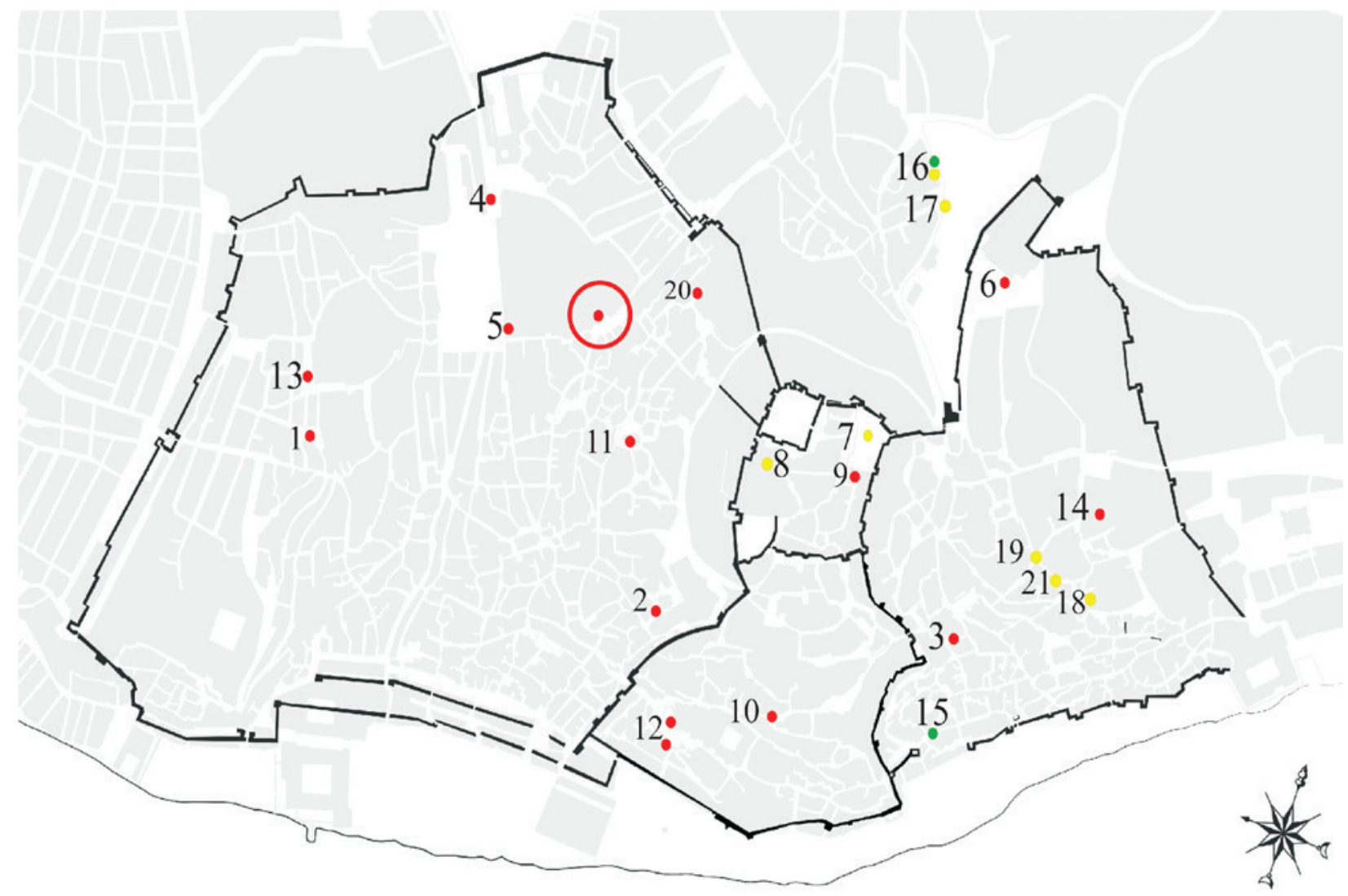

Legenda:

- Ritual Cristão

Ritual Islâmico

- Ritual Judaico ?

- Espaço funerário do Poço do Borratém

1- Igreja do Santíssimo Sacramento

2- Igreja de São Mamede (Rua de S.Mamede ao Caldas- VP)

3- Convento do Salvador

4- Igreja e Convento de S.Domingos (Largo de S.Domingos)

5- Praça da Figueira

6- Largo da Graça

7- Castelo de São Jorge - Praça Nova

8- Castelo de São Jorge - Palácio das Cozinhas

9- Castelo de São Jorge - Igreja de Santa Cruz (Largo de Santa Cruz)

10- Igreja de São Martinho
11- Igreja de Santa Maria de Alcamim (Igreja de São Cristóvão)

12- Sé e Cruzes da Sé

13- Igreja e Convento do Carmo

14- Mosteiro de São Vicente de Fora

15- Judiaria Pequena - Rua de S. Miguel, Alfama

16- "Almocávar Grande" (Rua dos Lagares n ${ }^{\circ} 74$ )

17- Rua dos Lagares n ${ }^{\circ} 24$

(Necrópole do Quarteirão dos Lagares)

18- Almocávar (Palácio de Santa Helena)

19- Almocávar (Largo de Santa Marinha)

20- Igreja de São Lourenço

21- Calçadinha do Tijolo n 37 - 43

Figura 7 - Dispersão dos contextos funerários intervencionados arqueologicamente na planta de Lisboa Medieval. 


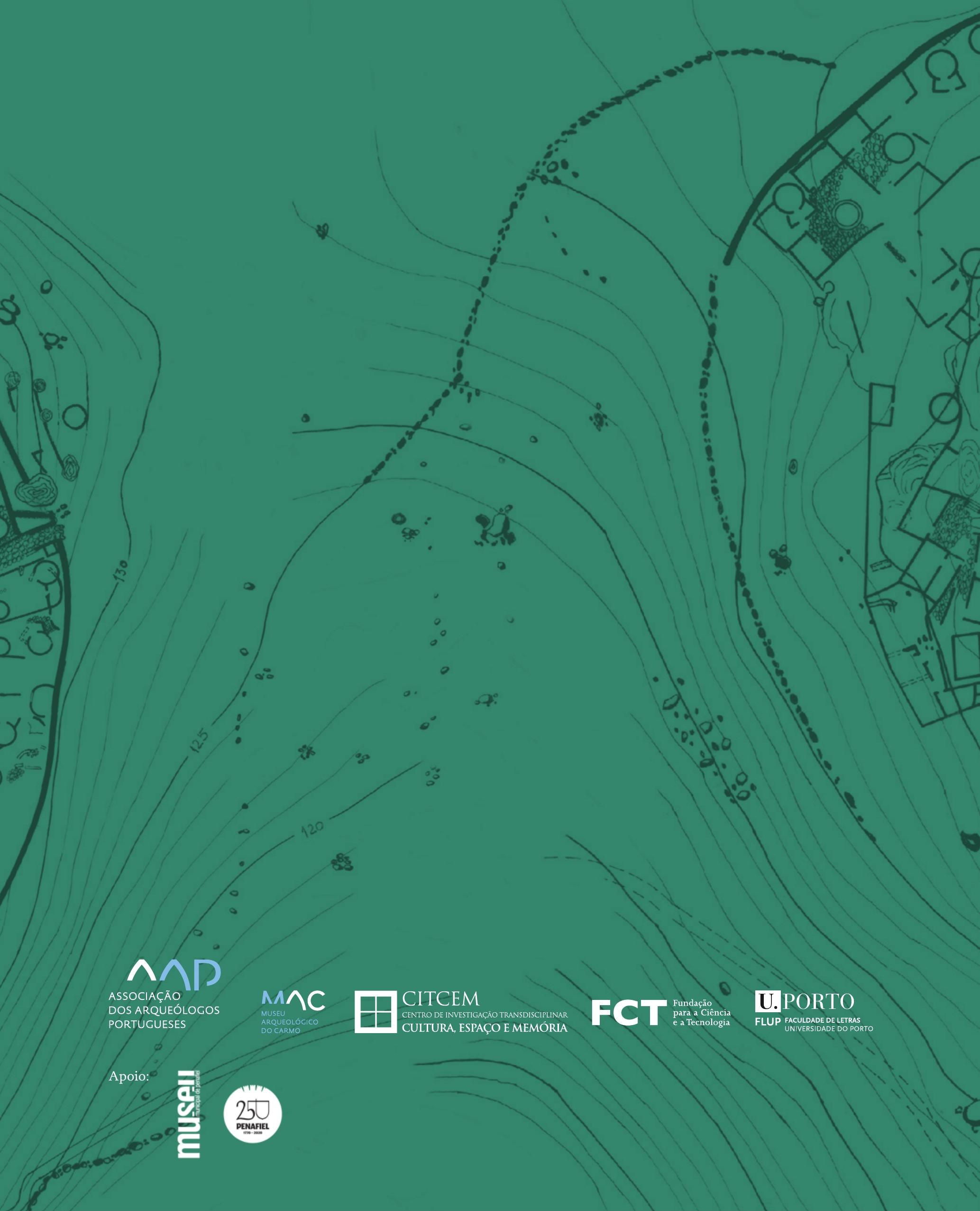

